\title{
Impacts of heterogeneous uptake of dinitrogen pentoxide and chlorine activation on ozone and reactive nitrogen partitioning: improvement and application of the WRF-Chem model in southern China
}

\author{
Qinyi Li ${ }^{1}$, Li Zhang ${ }^{1}$, Tao Wang ${ }^{1}$, Yee Jun Tham ${ }^{1}$, Ravan Ahmadov ${ }^{2,3}$, Likun Xue $^{4}$, Qiang Zhang ${ }^{5}$, and Junyu Zheng ${ }^{6}$ \\ ${ }^{1}$ Department of Civil and Environmental Engineering, The Hong Kong Polytechnic University, Hong Kong, China \\ ${ }^{2}$ Cooperative Institute for Research in Environmental Sciences, University of Colorado at Boulder, Boulder, CO, USA \\ ${ }^{3}$ Earth System Research Laboratory, National Oceanic and Atmospheric Administration, Boulder, CO, USA \\ ${ }^{4}$ Environment Research Institute, Shandong University, Ji’nan, China \\ ${ }^{5}$ Center for Earth System Science, Tsinghua University, Beijing, China \\ ${ }^{6}$ School of Environmental Science and Engineering, South China University of Technology, Guangzhou, China
}

Correspondence to: T. Wang (cetwang@polyu.edu.hk)

Received: 16 May 2016 - Published in Atmos. Chem. Phys. Discuss.: 1 June 2016

Revised: 31 August 2016 - Accepted: 23 October 2016 - Published: 1 December 2016

\begin{abstract}
The uptake of dinitrogen pentoxide $\left(\mathrm{N}_{2} \mathrm{O}_{5}\right)$ on aerosol surfaces and the subsequent production of nitryl chloride $\left(\mathrm{ClNO}_{2}\right)$ can have a significant impact on the oxidising capability and thus on secondary pollutants such as ozone. The range of such an impact, however, has not been well quantified in different geographical regions. In this study, we applied the Weather Research and Forecasting coupled with Chemistry (WRF-Chem) model to investigate the impact of the $\mathrm{N}_{2} \mathrm{O}_{5}$ uptake processes in the Hong Kong-Pearl River Delta (HK-PRD) region, where the highest ever reported $\mathrm{N}_{2} \mathrm{O}_{5}$ and $\mathrm{ClNO}_{2}$ concentrations were observed in our recent field study. We first incorporated into the WRF-Chem an aerosol thermodynamics model (ISORROPIA II), recent parameterisations for $\mathrm{N}_{2} \mathrm{O}_{5}$ heterogeneous uptake and $\mathrm{ClNO}_{2}$ production and gas-phase chlorine chemistry. The revised model was then used to simulate the spatiotemporal distribution of $\mathrm{N}_{2} \mathrm{O}_{5}$ and $\mathrm{ClNO}_{2}$ over the HK-PRD region and the impact of $\mathrm{N}_{2} \mathrm{O}_{5}$ uptake and $\mathrm{Cl}$ activation on ozone and reactive nitrogen in the planetary boundary layer (PBL). The updated model can generally capture the temporal variation of $\mathrm{N}_{2} \mathrm{O}_{5}$ and $\mathrm{ClNO}_{2}$ observed at a mountaintop site in Hong Kong, but it overestimates $\mathrm{N}_{2} \mathrm{O}_{5}$ uptake and $\mathrm{ClNO}_{2}$ production. The model results suggest that under average conditions, elevated levels of $\mathrm{ClNO}_{2}$ (>0.25 ppb within the PBL) are present in the south-western PRD, with the highest val-
\end{abstract}

ues $(>1.00 \mathrm{ppb})$ predicted near the ground surface $(0-200 \mathrm{~m}$ above ground level; a.g.l.). In contrast, during the night when very high levels of $\mathrm{ClNO}_{2}$ and $\mathrm{N}_{2} \mathrm{O}_{5}$ were measured in well-processed plumes from the PRD, $\mathrm{ClNO}_{2}$ is mostly concentrated within the residual layer $(\sim 300 \mathrm{~m}$ a.g.l. $)$. The addition of $\mathrm{N}_{2} \mathrm{O}_{5}$ heterogeneous uptake and $\mathrm{Cl}$ activation reduces the $\mathrm{NO}$ and $\mathrm{NO}_{2}$ levels by as much as $1.93 \mathrm{ppb}$ $(\sim 7.4 \%)$ and $4.73 \mathrm{ppb}(\sim 16.2 \%)$, respectively, and it increases the total nitrate and ozone concentrations by up to $13.45 \mu \mathrm{g} \mathrm{m}^{-3}(\sim 57.4 \%)$ and $7.23 \mathrm{ppb}(\sim 16.3 \%)$, respectively, in the PBL. Sensitivity tests show that the simulated chloride and $\mathrm{ClNO}_{2}$ concentrations are highly sensitive to chlorine emission. Our study suggests the need to measure the vertical profiles of $\mathrm{N}_{2} \mathrm{O}_{5} / \mathrm{ClNO}_{2}$ under various meteorological conditions, to consider the chemistry of $\mathrm{N}_{2} \mathrm{O}_{5} / \mathrm{ClNO}_{2}$ in the chemical transport model and to develop an updated chlorine emission inventory over China. 


\section{Introduction}

Dinitrogen pentoxide $\left(\mathrm{N}_{2} \mathrm{O}_{5}\right)$ is mostly produced by chemical reactions involving ozone $\left(\mathrm{O}_{3}\right)$ and nitrogen dioxide $\left(\mathrm{NO}_{2}\right)$.

$\mathrm{O}_{3}+\mathrm{NO}_{2} \longrightarrow \mathrm{NO}_{3}$

$\mathrm{NO}_{3}+\mathrm{NO}_{2} \longrightarrow \mathrm{N}_{2} \mathrm{O}_{5}$

The subsequent heterogeneous uptake of $\mathrm{N}_{2} \mathrm{O}_{5}$ produces nitrate on water-containing aerosol surfaces via Reaction (R3) (hydrolysis), and it produces both nitrate and gaseous nitryl chloride $\left(\mathrm{ClNO}_{2}\right)$ on chloride-containing aerosol surfaces via Reaction (R4) (Finlayson-Pitts et al., 1989; Osthoff et al., 2008). The net reaction of Reactions (R3) and (R4) could be treated as Reaction (R5), in which the $\mathrm{ClNO}_{2}$ yield, i.e. parameter $\phi$, represents the fraction of $\mathrm{N}_{2} \mathrm{O}_{5}$ that reacts via Reaction (R4). The produced $\mathrm{ClNO}_{2}$ can be further photolysed into $\mathrm{Cl}$ radical and $\mathrm{NO}_{2}$ (via Reaction $\mathrm{R} 6$ ).

$$
\begin{aligned}
& \mathrm{N}_{2} \mathrm{O}_{5}(g)+\mathrm{H}_{2} \mathrm{O}(\mathrm{aq}) \longrightarrow 2 \mathrm{HNO}_{3}(\mathrm{aq}) \\
& \mathrm{N}_{2} \mathrm{O}_{5}(g)+\mathrm{HCl}(\mathrm{aq}) \longrightarrow \mathrm{HNO}_{3}(\mathrm{aq})+\mathrm{ClNO}_{2}(g) \\
& \mathrm{N}_{2} \mathrm{O}_{5}(g)+(1-\phi) \mathrm{H}_{2} \mathrm{O}(\mathrm{aq})+\phi \mathrm{HCl}(\mathrm{aq}) \longrightarrow(1-\phi) \\
& \times 2 \mathrm{HNO}_{3}(\mathrm{aq})+\phi \times\left(\mathrm{HNO}_{3}(\mathrm{aq})+\mathrm{ClNO}_{2}(g)\right) \\
& \mathrm{ClNO}_{2}(g)+\mathrm{hv} \longrightarrow \mathrm{Cl}(g)+\mathrm{NO}_{2}(g)
\end{aligned}
$$

The above processes affect the fate and composition of the total reactive nitrogen $\left(\mathrm{NO}_{y}\right)$, which is the sum of $\mathrm{NO}, \mathrm{NO}_{2}$, $\mathrm{HNO}_{3}(g), 2 \times \mathrm{N}_{2} \mathrm{O}_{5}, \mathrm{NO}_{3}, \mathrm{ClNO}_{2}, \mathrm{PAN}, \mathrm{HONO}, \mathrm{HNO}_{4}$, aerosol nitrate and various organic nitrates. The hydrolysis of $\mathrm{N}_{2} \mathrm{O}_{5}$ is a major loss pathway for $\mathrm{NO}_{x}\left(=\mathrm{NO}+\mathrm{NO}_{2}\right)$ at night, reducing the amount of $\mathrm{NO}_{x}$ for daytime photochemistry in the following day, while producing nitrate aerosol contributing to secondary aerosol (Brown and Stutz, 2012). When $\mathrm{ClNO}_{2}$ is produced, it serves as a reservoir for reactive nitrogen at night, and it is photolysed to recycle $\mathrm{NO}_{2}$ and release highly reactive chlorine radicals ( $\mathrm{Cl}$ activation), both of which can significantly affect the daytime photochemistry, such as $\mathrm{O}_{3}$ formation via reactions with volatile organic compounds (VOCs; Atkinson, 2000; Thornton et al., 2010; Riedel et al., 2014).

The critical parameters required to determine the impacts of the $\mathrm{N}_{2} \mathrm{O}_{5}$ uptake processes are the rate constant of Reaction (R5), $k_{5}$, and the yield of $\mathrm{ClNO}_{2}, \phi . k_{5}$ can be calculated from Eq. (1) by treating the $\mathrm{N}_{2} \mathrm{O}_{5}$ heterogeneous uptake reaction as a first-order reaction (Chang et al., 2011):

$k_{5}=\frac{\mathrm{V}_{\mathrm{N}_{2} \mathrm{O}_{5}} \times \mathrm{S}_{\mathrm{aer}} \times \gamma}{4}$,

where $V_{\mathrm{N}_{2} \mathrm{O}_{5}}$ denotes the mean molecular velocity of $\mathrm{N}_{2} \mathrm{O}_{5}$, $S_{\text {aer }}$ is the aerosol surface area density and $\gamma$ represents the heterogeneous uptake coefficient of $\mathrm{N}_{2} \mathrm{O}_{5}$ which is the possibility that a collision of an $\mathrm{N}_{2} \mathrm{O}_{5}$ molecule with a particle will lead to uptake and a chemical reaction (Sarwar et al., 2012).
$V_{\mathrm{N}_{2} \mathrm{O}_{5}}$ and $S_{\text {aer }}$ are relatively well determined; therefore, the treatments of $\gamma$ and $\phi$ are crucial for the prediction of the impacts of $\mathrm{N}_{2} \mathrm{O}_{5}$ uptake and $\mathrm{Cl}$ activation. In terms of $\gamma$, a fixed value of 0.1 was first proposed (Dentener and Crutzen, 1993). Highly variable $\gamma$ values were then derived from observational campaigns, which showed differing values for inland and marine aerosols (e.g. Brown et al., 2006, 2009; Osthoff et al., 2008). Later, laboratory and modelling studies considered the dependence of $\gamma$ on the aerosol species/compositions (sea salt, black carbon, sulfate, nitrate, chloride, organic matter and water), temperature and/or relative humidity (Evans and Jacob, 2005 and the reference therein; Davis et al., 2008; Anttila et al., 2006; Riemer et al., 2009; Bertram and Thornton, 2009). Several parameterisations have been proposed for the yield of $\mathrm{ClNO}_{2}$. Simon et al. (2010) applied a constant value of 0.75 for the fraction of $\mathrm{N}_{2} \mathrm{O}_{5}$ involved in the production of $\mathrm{ClNO}_{2}$. More detailed parameterisations of $\phi$ considering the effects of aerosol compositions were proposed by Roberts et al. (2009) and by Bertram and Thornton (2009).

Several studies examined the impacts of $\mathrm{N}_{2} \mathrm{O}_{5}$ uptake or $\mathrm{ClNO}_{2}$ production with the use of the chemical transport model. Dentener and Crutzen (1993) evaluated the impacts of the $\mathrm{N}_{2} \mathrm{O}_{5}$ uptake on tropospheric aerosol by using a constant $\gamma(0.1)$, and their results showed a substantial decrease of $\mathrm{NO}_{x}(50 \%)$ and a slight reduction of $\mathrm{O}_{3}(9 \%)$ globally. Riemer et al. (2003) utilised a weighting factor on a constant $\gamma(0.02)$ to study the $\mathrm{N}_{2} \mathrm{O}_{5}$ heterogeneous hydrolysis, and their research showed small impacts on $\mathrm{O}_{3}$ and remarkable influences on nitrate formation in Europe. By applying parameterisations of $\gamma$ for various aerosol compositions and meteorological conditions, Evans and Jacob (2005) showed higher levels of $\mathrm{O}_{3}$ and $\mathrm{NO}_{x}$ compared to simulations with a $\gamma$ value of 0.1. Lowe et al. (2015) and Archer-Nicholls et al. (2014) incorporated the heterogeneous uptake of $\mathrm{N}_{2} \mathrm{O}_{5}$ on particles into the MOSAIC aerosol module in the Weather Research and Forecasting coupled with Chemistry (WRFChem) model based on the methods suggested by Bertram and Thornton (2009), Anttila et al. (2006) and Riemer et al. (2009). Their results suggested that $\mathrm{N}_{2} \mathrm{O}_{5}$ uptake suppressed VOC oxidation (by $\mathrm{OH}$ and $\mathrm{NO}_{3}$ ) by a factor of 1.5 and significantly enhanced nitrate formation during nighttime (an increase from 3.5 to $4.6 \mu \mathrm{g} \mathrm{kg}^{-1}$ ) over north-western Europe. Simon et al. (2009) used a gas-phase reaction to represent the heterogeneous production process of $\mathrm{ClNO}_{2}$, and their study predicted modest increases in $\mathrm{O}_{3}$ due to the $\mathrm{ClNO}_{2}$ production in Houston. Sarwar et al. (2012) implemented the heterogeneous production of $\mathrm{ClNO}_{2}$ based on the parameterisation proposed by Bertram and Thornton (2009) and additional gas-phase chlorine reactions in CMAQ, and they examined the impacts of $\mathrm{Cl}$ activation due to $\mathrm{ClNO}_{2}$ production and $\mathrm{Cl}$ chemistry on air quality. Their results showed that $\mathrm{ClNO}_{2}$ production reduced the total nitrate level (up to $0.8-2.0 \mu \mathrm{g} \mathrm{m}^{-3}$ or $11-21 \%$ ) and had modest impacts on the $8 \mathrm{~h} \mathrm{O}_{3}$ level (up to $1-2 \mathrm{ppb}$ or 3-4\%) in the United States. Sarwar et al. (2014) expanded the study region used 
in Sarwar et al. (2012) to the entire Northern Hemisphere, and they suggested that $\mathrm{ClNO}_{2}$ production had remarkable impacts on the air quality in China and western Europe, with enhancements of the $8 \mathrm{~h} \mathrm{O}_{3}$ level up to $7.0 \mathrm{ppb}$. Most previous studies focused on investigating the effects of $\mathrm{N}_{2} \mathrm{O}_{5}$ uptake or $\mathrm{ClNO}_{2}$ production in North America and Europe; however, little is known about Asia. The only study that covered Asia was performed by Sarwar et al. (2014); it used a coarse model resolution $(>100 \mathrm{~km})$ and considered only biomass burning and sea salt as the source of chloride.

Previous studies in Asia (Hong Kong) have revealed the existence and significance of $\mathrm{ClNO}_{2}$ in this region (Wang et al., 2014; Tham et al., 2014; Xue et al., 2015). In a recent field study, we observed the highest ever reported mixing ratios of $\mathrm{N}_{2} \mathrm{O}_{5}$ ( 1 min average value up to $7.7 \mathrm{ppbv}$ ) and $\mathrm{ClNO}_{2}$ ( $4.7 \mathrm{ppbv})$ at a mountaintop site ( $957 \mathrm{~m}$ above sea level) in Hong Kong (Brown et al., 2016; Wang et al., 2016). This result indicates rapid production of $\mathrm{N}_{2} \mathrm{O}_{5}$ and $\mathrm{ClNO}_{2}$ in the Hong Kong-Pearl River delta (HK-PRD) region, which has long suffered $\mathrm{O}_{3}$ and $\mathrm{NO}_{x}$ pollution (Wang et al., 2009). Meteorological analysis and chemical data revealed highly inhomogeneous dynamic and chemical processes and considerable impacts of the $\mathrm{ClNO}_{2}$ chemistry on the radical budget (up to $77 \%$ increase of $\mathrm{OH}$ ) and daytime $\mathrm{O}_{3}$ production (up to $41 \%$ ) in the high $\mathrm{ClNO}_{2}$ air mass as it transported to downwind locations above the ocean (Wang et al., 2016). It was also suggested in that study that other locations downwind of major urban areas under prevailing conditions may experience more frequent events with high levels of $\mathrm{ClNO}_{2} / \mathrm{N}_{2} \mathrm{O}_{5}$ than the site in Hong Kong. It is therefore of great interest to investigate the regional distribution of $\mathrm{N}_{2} \mathrm{O}_{5} / \mathrm{ClNO}_{2}$ and the impact of $\mathrm{N}_{2} \mathrm{O}_{5}$ uptake and subsequent chemistry.

This study was conducted to investigate (1) the spatial (horizontal and vertical) distribution of the $\mathrm{N}_{2} \mathrm{O}_{5}$ and $\mathrm{ClNO}_{2}$ concentrations in the HK-PRD region and (2) the spatial extent of the impact of $\mathrm{N}_{2} \mathrm{O}_{5}$ uptake processes on the formation of $\mathrm{O}_{3}$ and the partitioning of reactive nitrogen in this region. The latest version of a widely used aerosol thermodynamics model, ISORROPIA II (Fountoukis and Nenes, 2007), was incorporated into the MADE/VBS aerosol model. ISORROPIA II has the ability to simulate the equilibrium between hydrogen chloride $(\mathrm{HCl})$ and chloride, which is critical for the simulation of $\mathrm{N}_{2} \mathrm{O}_{5}$ heterogeneous uptake and $\mathrm{Cl}$ activation. However, this capacity is not considered in the current MADE/VBS model in WRF-Chem (Grell et al., 2005; Ahmadov et al., 2012). Up-to-date parameterisation for $\mathrm{N}_{2} \mathrm{O}_{5}$ uptake and $\mathrm{ClNO}_{2}$ production and Cl-radical-initiated chemistry were implemented into WRF-Chem. The revised WRFChem was then applied to southern China to investigate the spatial distribution of $\mathrm{N}_{2} \mathrm{O}_{5}$ and $\mathrm{ClNO}_{2}$ and the impacts of these processes on $\mathrm{O}_{3}$ and $\mathrm{NO}_{y}$. We start with a description of the data used to run and validate the simulations, the amendments to the WRF-Chem model and the model setup in Sect. 2. In Sect. 3, we show the performance of the
WRF-Chem model in the simulation of several air pollutants without $\mathrm{N}_{2} \mathrm{O}_{5}$ uptake processes and the simulation results of $\mathrm{N}_{2} \mathrm{O}_{5}$ and $\mathrm{ClNO}_{2}$ with $\mathrm{N}_{2} \mathrm{O}_{5}$ uptake and $\mathrm{Cl}$ activation processes; we then evaluate the impacts of $\mathrm{N}_{2} \mathrm{O}_{5}$ uptake and $\mathrm{Cl}$ activation on $\mathrm{NO}_{x}$, total nitrate and $\mathrm{O}_{3}$ and $\mathrm{NO}_{y}$ partitioning, and we test the sensitivity of the $\mathrm{ClNO}_{2}$ concentration to chlorine emissions. A summary is given in Sect. 4.

\section{Methodology}

\subsection{Data}

\subsubsection{Field measurement data}

$\mathrm{N}_{2} \mathrm{O}_{5}$ and $\mathrm{ClNO}_{2}$ concentrations were measured at Tai Mo Shan (TMS) in Hong Kong with a chemical ionisation mass spectrometer between 15 November and 5 December 2013 (refer to Wang et al., 2016, for more details). The measurements were made on a mountaintop in the south-eastern PRD at an altitude of $957 \mathrm{~m}$. Other major air pollutants, including $\mathrm{PM}_{2.5}, \mathrm{NO}_{2}$ and $\mathrm{O}_{3}$, were also measured at the TMS site and at 11 general (non-roadside) monitoring stations of the Hong Kong Environmental Protection Department (HKEPD; available at http://epic.epd.gov.hk/EPICDI/air/station/). Hourly measurement data were used to validate the performance of the WRF-Chem simulations.

\subsubsection{Emission data}

Four sets of anthropogenic emission inventories (EIs) covering different areas were adopted in this study. For mainland China, we used the Multi-resolution Emission Inventory for China (MEIC; available at http://meicmodel.org), developed by Tsinghua University for the year 2010. For the PRD, the anthropogenic EI developed by the Southern China University of Technology was applied. The anthropogenic EI developed by HKEPD was used over Hong Kong. INTEX-B EI (Zhang et al., 2009) was adopted for other Asian regions. Readers are referred to Zhang et al. (2016) for the details of these anthropogenic EIs. For natural emissions, the biogenic emission parameterisation proposed by Guenther et al. (1994), the dust emission parameterisation proposed by Shaw et al. (2008) and the sea salt emission parameterisation proposed by Gong et al. (2002) were adopted in this study. The concentrations of sodium, chloride, calcium, magnesium and potassium in dust and sea salt follow those suggested by Millero (1996) and Wedepohl (1995), as shown in Table S1 in the Supplement.

Chlorine emissions are not included in most EIs, but they are critical for the simulation of $\mathrm{N}_{2} \mathrm{O}_{5}$ uptake and $\mathrm{Cl}$ activation. In this study, the Reactive Chlorine Emission Inventory (RCEI; Keene et al., 1999 and references therein, available at http://eccad.sedoo.fr/eccad_ extract_interface/JSF/page_login.jsf), with a resolution of $1^{\circ} \times 1^{\circ}$, was adopted to provide chlorine emissions, in- 
cluding emissions from biomass burning (particulate phase) and anthropogenic activities (gas phase; e.g. coal combustion). Global chlorine emissions from biomass burning and anthropogenic activities are estimated to be $\sim 6.3$ and $\sim 6.6 \mathrm{Tg} \mathrm{Cl} \mathrm{yr}^{-1}$, respectively. The RCEI inventory is the only available chlorine EI that currently covers China, and it is subject to some, probably large, uncertainties for representing $\mathrm{Cl}$ emissions in the HK-PRD region due to its low spatial resolution and the fact that it was compiled for the year 1990. Coal consumption and $\mathrm{SO}_{2}$ emissions from coalfired power plants in China increased by 479 and $56 \%$ from 1990 to 2010, respectively (Liu et al., 2015); thus it is expected that chlorine emissions from coal combustion, which form a large proportion of anthropogenic chlorine (Keene et al., 1999), also increased significantly over that period. We conducted two sensitivity simulations by adjusting the chlorine emissions to test the dependence of the chloride and $\mathrm{ClNO}_{2}$ concentrations on the varied chlorine emissions; the results are shown in Section 3.5.

\subsubsection{Meteorological data}

Three-hourly meteorological measurements, including atmospheric pressure, temperature, relative humidity, wind direction and wind speed, at $\sim 2500$ surface meteorological stations and 12-hourly data at $\sim 250$ sounding stations, were obtained from the China Meteorological Agency (CMA) and Hong Kong Observatory and were adopted in 4-D data assimilation to improve the model performance of the meteorological fields using observational nudging techniques (Zhang et al., 2016). The FNL Operational Global Analysis dataset provided by the National Centers for Environmental Prediction (available at http://rda.ucar.edu/datasets/ds083.2/) was used for analysis nudging. Observational and analytical nudging techniques have been shown to improve the performance of meteorological simulation in both northern China (Zhang et al., 2015) and southern China (Zhang et al., 2016). Hourly datasets from $\sim 500$ surface meteorological observation stations obtained from the CMA were used to validate the meteorological simulations.

\subsection{Model development}

\subsubsection{Incorporation of ISORROPIA II}

ISORROPIA II, an aerosol thermodynamics model developed by Nenes et al. (1998) and Fountoukis and Nenes (2007), was incorporated to replace the aerosol thermodynamics module in the MADE/VBS aerosol model in the original WRF-Chem v3.5 so as to extend the capacity of simulation of the equilibrium between $\mathrm{PM}_{2.5}$ compositions and their corresponding gaseous species. The MADE/VBS model adopts a volatility basis set model to simulate secondary organic aerosol (SOA) formation, and it provides improved simulations of SOA compared to the traditional
MADE/SORGAM model (Ahmadov et al., 2012). The current MADE/VBS model only estimates the thermodynamic equilibrium between $\mathrm{SO}_{4}^{2-}, \mathrm{NO}_{3}^{-}, \mathrm{NH}_{4}^{+}, \mathrm{H}_{2} \mathrm{O}$ and corresponding gases, whereas ISORROPIA II simulates the equilibrium between $\mathrm{SO}_{4}^{2-}, \mathrm{NO}_{3}^{-}, \mathrm{NH}_{4}^{+}, \mathrm{H}_{2} \mathrm{O}, \mathrm{Na}^{+}, \mathrm{Cl}^{-}, \mathrm{Ca}^{2+}$, $\mathrm{Mg}^{2+}, \mathrm{K}^{+}$and associated gases.

\subsection{2 $\mathrm{N}_{2} \mathrm{O}_{5}$ heterogeneous uptake, $\mathrm{ClNO}_{2}$ production and $\mathrm{Cl}$ gaseous reaction}

We adopted the parameterisations of $\mathrm{N}_{2} \mathrm{O}_{5}$ heterogeneous uptake and $\mathrm{ClNO}_{2}$ production suggested by Bertram and Thornton (2009). According to the parameterisations, the $\mathrm{N}_{2} \mathrm{O}_{5}$ heterogeneous uptake coefficient, $\gamma$, can be calculated with the following equation:

$\gamma=A k\left(1-\frac{1}{\left(\frac{0.06\left[\mathrm{H}_{2} \mathrm{O}(1)\right]}{\left[\mathrm{NO}_{3}^{-}\right]}\right)+1+\left(\frac{29\left[\mathrm{Cl}^{-}\right]}{\left[\mathrm{NO}_{3}^{-}\right]}\right)}\right)$,

where $A=3.2 \times 10^{-8}, k=1.15 \times 10^{6} \times\left(1-e^{\left(-0.13\left[\mathrm{H}_{2} \mathrm{O}(l)\right]\right)}\right)$, and $\left[\mathrm{H}_{2} \mathrm{O}(1)\right],\left[\mathrm{NO}_{3}^{-}\right]$and $\left[\mathrm{Cl}^{-}\right]$are the molarities of liquid water, nitrate and chloride in aerosol volume. The yield of $\mathrm{ClNO}_{2}, \phi$, can be calculated with the following equation:

$\phi=\left(1+\frac{\left[\mathrm{H}_{2} \mathrm{O}(l)\right]}{483\left[\mathrm{Cl}^{-}\right]}\right)^{-1}$.

The loss of $\mathrm{N}_{2} \mathrm{O}_{5}$ and the production of nitrate and $\mathrm{ClNO}_{2}$ can be predicted with Eqs. (1)-(3). The produced $\mathrm{ClNO}_{2}$ is then photolysed, releasing a $\mathrm{Cl}$ atom, which further oxidises VOCs like an $\mathrm{OH}$ radical. The $\mathrm{Cl}$-initiated gaseous chemistry used in this study was originally designed for the CB05 mechanism by Sarwar et al. (2012) and was modified for the RACM_ESRL mechanism (detail reactions are shown in Table S2). RACM_ESRL mechanism is the updated Regional Atmospheric Chemistry Mechanism in WRF-Chem based on the original version in Stockwell et al. (1997). The photolysis rates of $\mathrm{Cl}_{2}, \mathrm{HOCl}, \mathrm{ClNO}_{2}$ and formyl chloride (FMCl) were calculated with the absorption cross section and quantum yield obtained from Atkinson et al. (2007) and Atkinson et al. (2008).

We implemented the $\mathrm{N}_{2} \mathrm{O}_{5}$ heterogeneous uptake, the $\mathrm{ClNO}_{2}$ production and the Cl-initiated reactions into the MADE/VBS aerosol model, RACM_ESRL gas-phase mechanism and Madronich photolysis model (Madronich, 1987) in the "RACM_SOA_VBS_KPP" chemistry option in WRFChem v3.5.

\subsection{Model set-up}

\subsubsection{Model configuration}

The model configurations of WRF-Chem used in this study are shown in Table 1 . We used the Noah model to simulate the land surface process, the YSU module to simu- 
Table 1. Model configuration.

\begin{tabular}{lll}
\hline WRF-Chem modules & Parameterisation options & Reference \\
\hline Land surface & Noah land surface model & Chen and Dudhia (2001) \\
PBL scheme & YSU & Hong et al. (2006) \\
Microphysics & Purdue Lin scheme & Lin et al. (1983) \\
$\begin{array}{l}\text { Cumulus } \\
\text { Shortwave and }\end{array}$ & Grell 3-D ensemble & Grell and Devenyi (2002) \\
longwave radiation & RRTMG & Iacono et al. (2008) \\
Gas chemistry & RACM_ESRL & Updated version based on \\
Aerosol & & Stockwell et al. (1997) \\
Photolysis & MADE/VBS & Ahmadov et al. (2012) \\
\hline
\end{tabular}

Table 2. Simulation cases.

\begin{tabular}{lll}
\hline Cases & $\begin{array}{l}\text { Aerosol } \\
\text { thermodynamics module }\end{array}$ & $\mathrm{N}_{2} \mathrm{O}_{5}$ and $\mathrm{ClNO}_{2}$ chemistry \\
\hline Base & ISORROPIA II & None \\
$\mathrm{HET}$ & ISORROPIA II & $\begin{array}{l}\mathrm{N}_{2} \mathrm{O}_{5} \text { heterogeneous uptake, } \\
\text { no } \mathrm{ClNO}_{2} \text { production }\end{array}$ \\
$\mathrm{HET}+\mathrm{Cl}$ & ISORROPIA II & $\begin{array}{l}\mathrm{N}_{2} \mathrm{O}_{5} \text { heterogeneous uptake, } \mathrm{ClNO}_{2} \\
\text { production and gas-phase } \mathrm{Cl} \text { reactions }\end{array}$ \\
& &
\end{tabular}

late the planetary boundary layer (PBL) processes, the Purdue Lin scheme to predict the microphysics, the Grell 3D ensemble module to simulate the cumulus, the RRTMG model to predict shortwave and longwave radiation and the RACM_ESRL, MADE/VBS and Madronich modules to simulate gas-phase chemistry, aerosol processes and photolysis.

Model simulations were conducted in four domains covering eastern Asia, southern China, the PRD and Hong Kong, with spatial resolutions of 27, 9, 3 and $1 \mathrm{~km}$, respectively (see Fig. 1a). High grid resolutions were adopted in this study to capture the extremely inhomogeneous terrain, with land and sea, mountain and plains and urban and forested areas, as shown in the terrain map of domain 2 (southern China) in Fig. 1b. The red dotted line in Fig. 1b represents the vertical cross-section domain that intercepts the most polluted part of the PRD and follows the prevailing (north-east) wind direction. The vertical domain is used to illustrate the vertical distribution of the $\mathrm{N}_{2} \mathrm{O}_{5}$ and $\mathrm{ClNO}_{2}$ concentrations and the impacts of $\mathrm{N}_{2} \mathrm{O}_{5}$ uptake processes in southern China. Thirty vertical model layers were adopted, of which eight layers are below 1000m (approximately the height of PBL at noon) to provide more detailed information within the PBL.

\subsubsection{Simulation cases}

Three simulation cases, shown in Table 2, were conducted from 15 November to 5 December 2013, during which $\mathrm{ClNO}_{2}$ and $\mathrm{N}_{2} \mathrm{O}_{5}$ levels were measured at the TMS site. All simulations used ISORROPIA II as the aerosol thermodynamics module. Note that the base case did not include $\mathrm{N}_{2} \mathrm{O}_{5}$ heterogeneous uptake (or $\mathrm{ClNO}_{2}$ chemistry). The $\mathrm{HET}+\mathrm{Cl}$ case included the complete $\mathrm{N}_{2} \mathrm{O}_{5}$ uptake and $\mathrm{Cl}$ activation processes, i.e. $\mathrm{N}_{2} \mathrm{O}_{5}$ loss on aerosol, $\mathrm{ClNO}_{2}$ production and gaseous chlorine reactions. Differences in chemical concentrations between the base and $\mathrm{HET}+\mathrm{Cl}$ cases, i.e. $\mathrm{HET}+\mathrm{Cl}-$ base, represent the impacts of $\mathrm{N}_{2} \mathrm{O}_{5}$ uptake and $\mathrm{Cl}$ activation. To estimate the relative contribution of $\mathrm{N}_{2} \mathrm{O}_{5}$ uptake vs. $\mathrm{Cl}$ activation to $\mathrm{O}_{3}$ and $\mathrm{NO}_{y}$ partitioning, the HET case was also conducted, which included $\mathrm{N}_{2} \mathrm{O}_{5}$ uptake but not $\mathrm{ClNO}_{2}$ production (i.e. $\mathrm{ClNO}_{2}$ yield, $\phi$, was set to 0 ) and therefore producing only nitrate from $\mathrm{N}_{2} \mathrm{O}_{5}$ uptake. The changes from the base case to the HET case (HET-base) represent the impacts of $\mathrm{N}_{2} \mathrm{O}_{5}$ heterogeneous uptake, whereas the changes from the HET case to the $\mathrm{HET}+\mathrm{Cl}$ case $(\mathrm{HET}+\mathrm{Cl}-\mathrm{HET})$, represent the impacts of $\mathrm{Cl}$ activation.

\section{Results and discussion}

\subsection{Model performance of WRF-Chem without $\mathrm{N}_{2} \mathrm{O}_{5}$ uptake and $\mathrm{Cl}$ activation}

The meteorological simulation determines the simulations of the transport of the air pollutants and therefore is crucial to the simulations of the spatial distributions of the atmospheric chemical species and their impacts. The performance of the meteorological module during the study period has been validated in Wang et al. (2016), which showed that atmospheric flow and other meteorological parameters were satisfactorily 


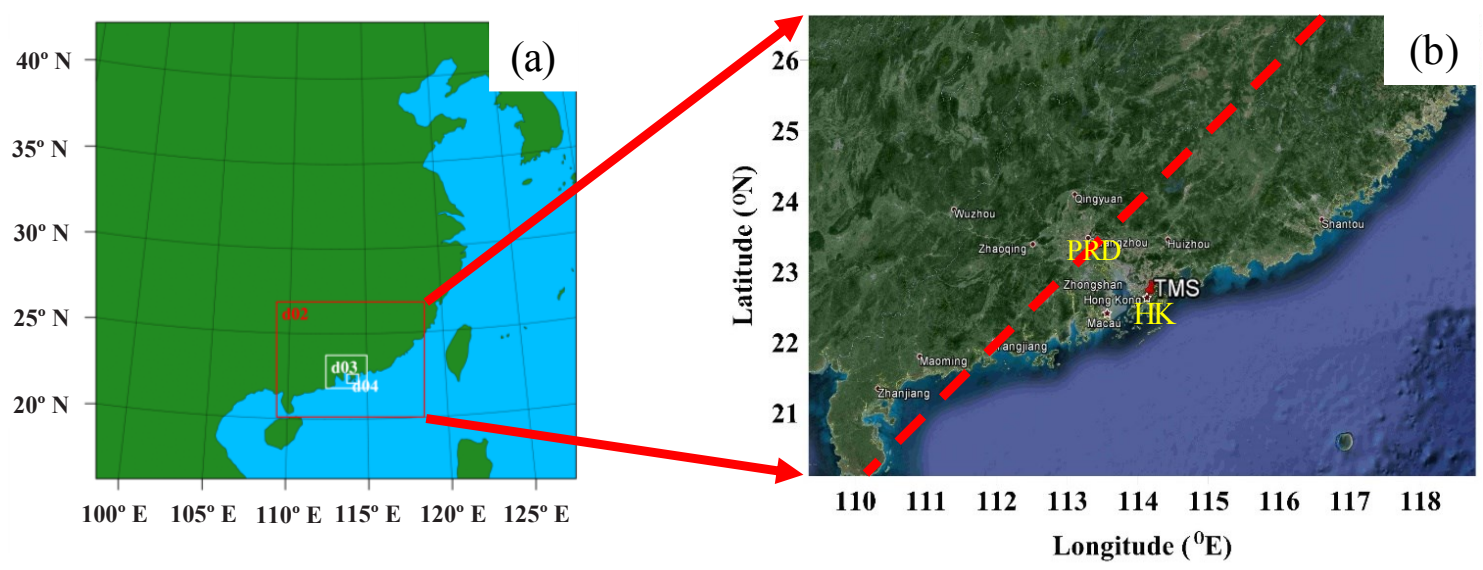

Figure 1. (a) Domain settings of WRF-Chem simulations and (b) the terrain in domain 2 (southern China). The red dotted line represents the vertical domain that intercepts the most polluted PRD region along the prevailing wind direction (north-east). TMS is the location of the site where $\mathrm{N}_{2} \mathrm{O}_{5}$ and $\mathrm{ClNO}_{2}$ were measured. $\mathrm{HK}$ and PRD are the general locations of Hong Kong and the Pearl River Delta region.

Table 3. Comparison of chemical simulation with observation for the base case and the HET $+\mathrm{Cl}$ case.

\begin{tabular}{lrrrr|rrrr}
\hline & \multicolumn{3}{c}{ Base } & \multicolumn{3}{c}{$\mathrm{HET}+\mathrm{Cl}$} \\
\cline { 2 - 8 } & $\begin{array}{r}\mathrm{PM}_{2.5} \\
\left(\mu \mathrm{g} \mathrm{m}^{-3}\right)\end{array}$ & $\begin{array}{r}\mathrm{NO}_{2} \\
(\mathrm{ppb})\end{array}$ & $\begin{array}{r}\mathrm{O}_{3} \\
(\mathrm{ppb})\end{array}$ & $\begin{array}{r}1 \text { h daily maximum } \\
\mathrm{O}_{3}(\mathrm{ppb})\end{array}$ & $\begin{array}{r}\mathrm{PM}_{2.5} \\
\left(\mu \mathrm{g} \mathrm{m}^{-3}\right)\end{array}$ & $\begin{array}{r}\mathrm{NO}_{2} \\
(\mathrm{ppb})\end{array}$ & $\begin{array}{r}\mathrm{O}_{3} \\
(\mathrm{ppb})\end{array}$ & $\begin{array}{r}1 \mathrm{~h} \text { daily maximum } \\
\mathrm{O}_{3}(\mathrm{ppb})\end{array}$ \\
\hline Observation average & 37.43 & 33.67 & 28.29 & 50.98 & 37.43 & 33.67 & 28.29 & 50.98 \\
Simulation average & 48.08 & 28.81 & 15.06 & 34.04 & 49.63 & 26.48 & 17.30 & 38.34 \\
Normalised mean bias & $28.5 \%$ & $-14.4 \%$ & $-46.8 \%$ & $-33.2 \%$ & $32.6 \%$ & $-21.4 \%$ & $-38.8 \%$ & $-24.8 \%$ \\
Fac2* & 0.69 & 0.71 & 0.46 & 0.86 & 0.69 & 0.70 & 0.50 & 0.92 \\
\hline
\end{tabular}

* Fac2 is defined as the fraction of the simulations that are within a factor of 2 of the observations.

simulated. The reader is referred to Wang et al. (2016) for further details.

The chemical simulation results of WRF-Chem without $\mathrm{N}_{2} \mathrm{O}_{5}$ heterogeneous uptake and $\mathrm{Cl}$ activation, i.e. the base case, were validated against hourly observations of several major air pollutants measured at 11 HKEPD stations and at the TMS site. $\mathrm{PM}_{2.5}, \mathrm{NO}_{2}$ and $\mathrm{O}_{3}$ were selected as the validation species because they act as the reaction surface $\left(\mathrm{PM}_{2.5}\right)$ or precursors $\left(\mathrm{NO}_{2}\right.$ and $\left.\mathrm{O}_{3}\right)$ for $\mathrm{N}_{2} \mathrm{O}_{5}$ and $\mathrm{ClNO}_{2}$ production. As shown in Table 3, the validation results for HKEPD stations indicate that the base case simulated the major air pollutants reasonably well in this region but overestimated $\mathrm{PM}_{2.5}$, slightly underestimated $\mathrm{NO}_{2}$ and underestimated $\mathrm{O}_{3}$. The base case also generally reproduced the observed temporal variations of $\mathrm{PM}_{2.5}, \mathrm{NO}_{2}$ and $\mathrm{O}_{3}$ at the HKEPD stations and the TMS site (Fig. S1a, b, c in the Supplement), and simulated the level of aerosol surface area density and particulate nitrate at TMS (Fig. S1d, e). It should be noted that the technique for measuring $\mathrm{NO}_{2}$ by the HKEPD, which is similar to that used in the regular air monitoring networks in North America and Europe, employs catalytic conversion that overmeasures $\mathrm{NO}_{2}$ (e.g. Xu et al., 2013). The discrepancy between the simulated and observed major air pollutants in this area is expected to affect the simulations of
$\mathrm{N}_{2} \mathrm{O}_{5}$ and $\mathrm{ClNO}_{2}$, which will be discussed in Sect. 3.2.1. The model performance of major air pollutants of the base case is within the acceptable range and is similar to our previous applications of WRF-Chem (Zhang et al., 2015, 2016) and other WRF-Chem model studies (e.g. Li et al., 2011).

The simulated fine chloride concentrations in the base case were compared with observations from several campaigns, as shown in Table 4. Tan et al. (2009) reported average concentrations of 1.19 and $8.37 \mu \mathrm{g} \mathrm{m}^{-3}$ at an urban site in Guangzhou (GZ) in the PRD on normal days and hazy days in winter, respectively; in comparison, the base case simulated an average level of $2.51 \mathrm{\mu g} \mathrm{m}^{-3}$ at that location. Tao et al. (2014) reported an average level of $3.30 \mu \mathrm{g} \mathrm{m}^{-3}$ in winter at the station of the South China Institute of Environmental Science (SCIES) in Guangzhou; the base case predicted $2.13 \mu \mathrm{g} \mathrm{m}^{-3}$ at this location. At the Tung Chung (TC) site in Hong Kong, we had previously measured an average level of $1.10 \mathrm{\mu g} \mathrm{m}^{-3}$ of chloride in $\mathrm{PM}_{2.5}$ in late autumn and early winter, while the base case simulated $0.32 \mu \mathrm{g} \mathrm{m}^{-3}$. At the TMS site, an average level $0.37 \mu \mathrm{g} \mathrm{m}^{-3}$ of chloride was observed during the campaign (which was also the simulation period of this study), while the base case predicted $0.14 \mu \mathrm{g} \mathrm{m}^{-3}$. The simulated chloride level in the base case was of the same order of magnitude with observations over 
Table 4. Comparison of measured and simulated chloride (base case).

\begin{tabular}{llcc}
\hline Location & Period & $\begin{array}{c}\text { Average measured } \\
\text { concentration }\left(\mu \mathrm{g} \mathrm{m}^{-3}\right)\end{array}$ & $\begin{array}{c}\text { Average simulated } \\
\text { concentration }\left(\mu \mathrm{g} \mathrm{m}^{-3}\right)^{\mathrm{e}}\end{array}$ \\
\hline GZ & $2007 / 12 / 31$ to $2008 / 1 / 12$ normal day & $1.19^{\mathrm{a}}$ & 2.51 \\
GZ & $2007 / 12 / 31$ to $2008 / 1 / 12$ haze day & $8.37^{\mathrm{a}}$ & 2.51 \\
SCIES, GZ & $2009-2010$ winter & $3.30^{\mathrm{b}}$ & 2.13 \\
TC, HK & $2011 / 10 / 25$ to 2011/12/7 & $1.10^{\mathrm{c}}$ & 0.32 \\
TMS, HK & $2013 / 11 / 15$ to 2013/12/5 & $0.37^{\mathrm{d}}$ & 0.14 \\
\hline
\end{tabular}

${ }^{\text {a }}$ Tan et al. (2009). ${ }^{\text {b }}$ Tao et al. (2014). ${ }^{\mathrm{c}}$ Unpublished data. ${ }^{d}$ Wang et al. (2016). ${ }^{\text {e }}$ The time period used to calculate the average simulated concentration is the entire simulation period (15 November to 5 December 2013).

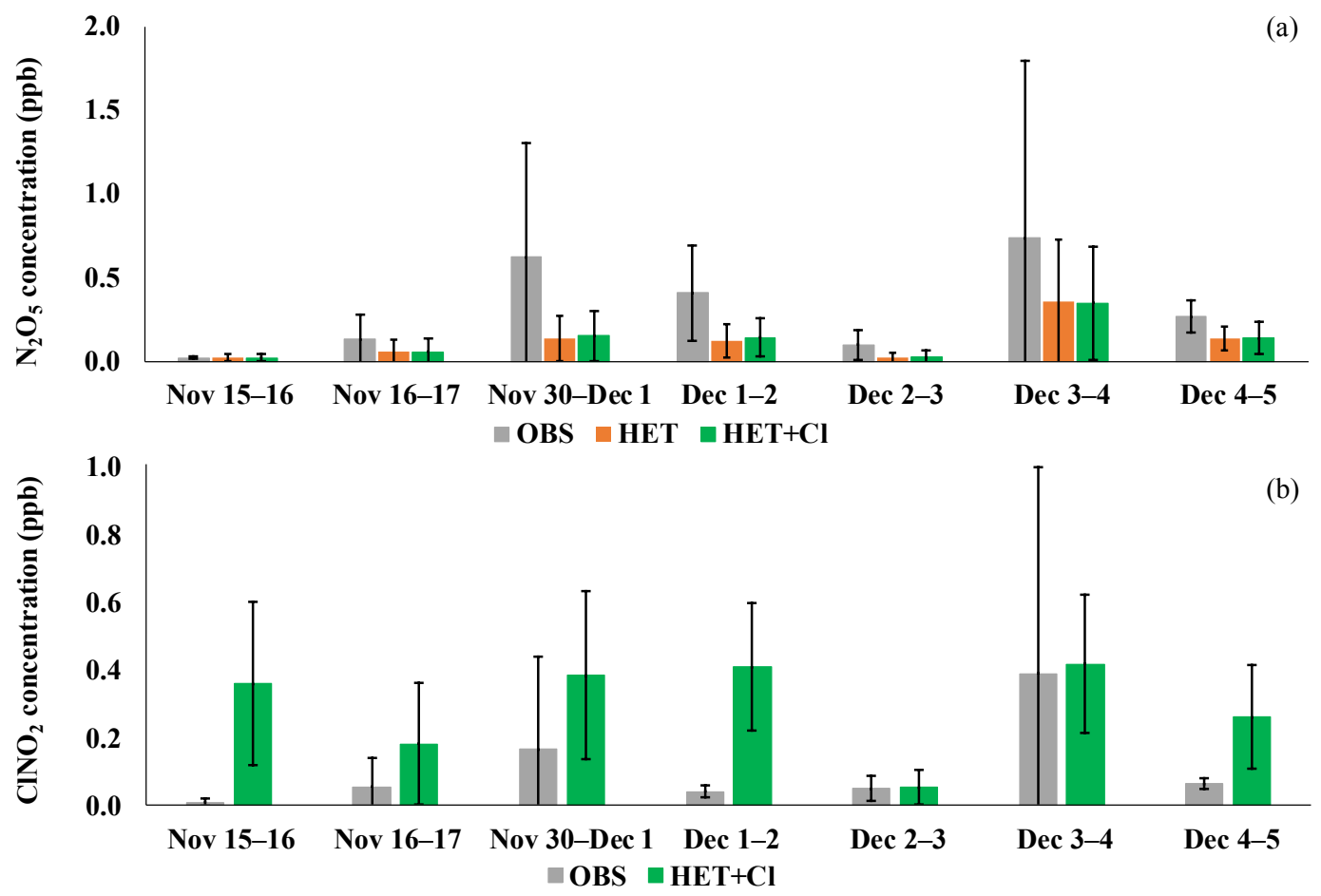

Figure 2. Comparison of simulated and observed average (a) $\mathrm{N}_{2} \mathrm{O}_{5}$ and (b) $\mathrm{ClNO}_{2}$ concentrations each night at the TMS site. Error bars represent the standard deviation.

the PRD, but it still underpredicted the observed chloride level due to the expected underestimates of chlorine sources in the EI we applied (see Sect. 2.1.2).

The simulated ratio of aerosol surface area to volume ranges between $0.5 \times 10^{7}$ and $2.5 \times 10^{7} \mathrm{~m}^{-1}$ (Fig. S2), which is comparable with the value $\left(2.67 \times 10^{7} \mathrm{~m}^{-1}\right)$ used in the parameterisation of $\mathrm{N}_{2} \mathrm{O}_{5}$ uptake coefficient on aerosol proposed by Bertram and Thornton (2009).

Overall, the validations of the meteorological and chemical simulations suggest that the model is capable of capturing the general characteristics of air flow and key atmospheric chemical processes and hence can provide a basis for further simulation of the distributions of the $\mathrm{N}_{2} \mathrm{O}_{5}$ and $\mathrm{ClNO}_{2}$ concentrations and the impacts of $\mathrm{N}_{2} \mathrm{O}_{5}$ uptake and $\mathrm{Cl}$ activation on $\mathrm{NO}_{y}$ partitioning and $\mathrm{O}_{3}$ production.

\subsection{Simulation of $\mathrm{N}_{2} \mathrm{O}_{5}$ and $\mathrm{ClNO}_{2}$ with $\mathrm{N}_{2} \mathrm{O}_{5}$ uptake and $\mathrm{Cl}$ activation}

\subsubsection{Comparison of simulated $\mathrm{N}_{2} \mathrm{O}_{5}$ and $\mathrm{CINO}_{2}$ with observation}

The average observed and simulated (HET $+\mathrm{Cl}$ case) concentrations of $\mathrm{N}_{2} \mathrm{O}_{5}$ and $\mathrm{ClNO}_{2}$ were calculated for each night, as shown in Fig. 2. The mean observed $\mathrm{N}_{2} \mathrm{O}_{5}$ concentrations for each night varied from 0.02 to $0.74 \mathrm{ppb}$ during the study period, while the average simulated $\mathrm{N}_{2} \mathrm{O}_{5}$ values from the $\mathrm{HET}+\mathrm{Cl}$ case were between 0.02 and $0.35 \mathrm{ppb}$. The HET $+\mathrm{Cl}$ case reproduced the order of $\mathrm{N}_{2} \mathrm{O}_{5}$ concentrations but underestimated them within a factor of 3. Differences between the HET case and $\mathrm{HET}+\mathrm{Cl}$ case in the 
simulated $\mathrm{N}_{2} \mathrm{O}_{5}$ were unnoticeable. For $\mathrm{ClNO}_{2}$, the average observed concentrations varied from 0.01 to $0.39 \mathrm{ppb}$, whilst the mean simulated values for each night varied between 0.05 and $0.42 \mathrm{ppb}$. The HET $+\mathrm{Cl}$ case reproduced the order of $\mathrm{ClNO}_{2}$ concentrations with an overestimate, mostly within a factor of 4 . The simulated and observed hourly concentrations of $\mathrm{N}_{2} \mathrm{O}_{5}$ and $\mathrm{ClNO}_{2}$ are shown in Fig. S3, indicating that the HET and HET $+\mathrm{Cl}$ case captured the temporal variations of these two compounds in general.

The underpredicted $\mathrm{N}_{2} \mathrm{O}_{5}$ and overpredicted $\mathrm{ClNO}_{2}$ values in the $\mathrm{HET}+\mathrm{Cl}$ case point to the underestimation of the sources and/or the overestimation of the sink of $\mathrm{N}_{2} \mathrm{O}_{5}$ and the overestimation of the production of $\mathrm{ClNO}_{2}$. As shown in Sect. 3.1, the simulated $\mathrm{NO}_{2}$ and $\mathrm{O}_{3}$ levels in the HKPRD region are lower than the observations, which results in lower production of $\mathrm{N}_{2} \mathrm{O}_{5}$; the simulated $\mathrm{PM}_{2.5}$ concentrations are higher than the observed values, which would lead to an overestimate of $\mathrm{N}_{2} \mathrm{O}_{5}$ heterogeneous loss. The observation-derived $\mathrm{N}_{2} \mathrm{O}_{5}$ uptake coefficients at the TMS site (Brown et al., 2016) varied from 0.004 to 0.029, with an average value of 0.014 , whilst the simulated uptake coefficients ranged from 0.008 to 0.031 , with an average of 0.019 , which suggests that the $\mathrm{HET}+\mathrm{Cl}$ simulation generally overestimates $\mathrm{N}_{2} \mathrm{O}_{5}$ uptake coefficients, which causes further overestimation of the loss of $\mathrm{N}_{2} \mathrm{O}_{5}$. The reactive uptake coefficient could be overestimated because the parameterisation used in this study does not consider the inhibition of organic coating to the uptake coefficient (Bertram and Thornton, 2009). The overestimated loss of $\mathrm{N}_{2} \mathrm{O}_{5}$ on aerosol inherently overestimated the production of $\mathrm{ClNO}_{2}$. The parameterisations used in this study are likely to overestimate the $\mathrm{CINO}_{2}$ yield (Kim et al., 2014; Ryder et al., 2015), which would further overestimate the production of $\mathrm{ClNO}_{2}$. In addition, the overpredicted $\mathrm{ClNO}_{2}$ could also be due to the ignorance of possible $\mathrm{ClNO}_{2}$ sinks (e.g. Roberts et al., 2008).

Discrepancies between the measured and simulated $\mathrm{N}_{2} \mathrm{O}_{5}$ and $\mathrm{ClNO}_{2}$ levels have also been reported in previous model studies. Lowe et al. (2015) used the same parameterisations for $\mathrm{N}_{2} \mathrm{O}_{5}$ uptake that we applied in our study and showed slightly higher average simulated $\mathrm{N}_{2} \mathrm{O}_{5}$ values along two flight tracks but simulated $\mathrm{N}_{2} \mathrm{O}_{5}$ in another flight a factor of 1-2 lower. They noted that the underestimated $\mathrm{N}_{2} \mathrm{O}_{5}$ could be attributed to inaccuracies in the meteorological simulation. Sarwar et al. (2012) used the parameterisation for $\mathrm{N}_{2} \mathrm{O}_{5}$ uptake proposed by Davis et al. (2008) and by Bertram and Thornton et al. (2009) and yielded a slightly higher simulated peak value of $\mathrm{ClNO}_{2}$ than the observed value in field studies conducted at different times from the model simulations. The authors attributed the overestimate of $\mathrm{ClNO}_{2}$ to the overestimated $\mathrm{N}_{2} \mathrm{O}_{5}$ uptake in the parameterisations. Sarwar et al. (2014) predicted lower peak values of $\mathrm{ClNO}_{2}$ than the observations and suggested that the underestimated $\mathrm{ClNO}_{2}$ could be attributed to a relatively low model resolution $(108 \mathrm{~km})$.
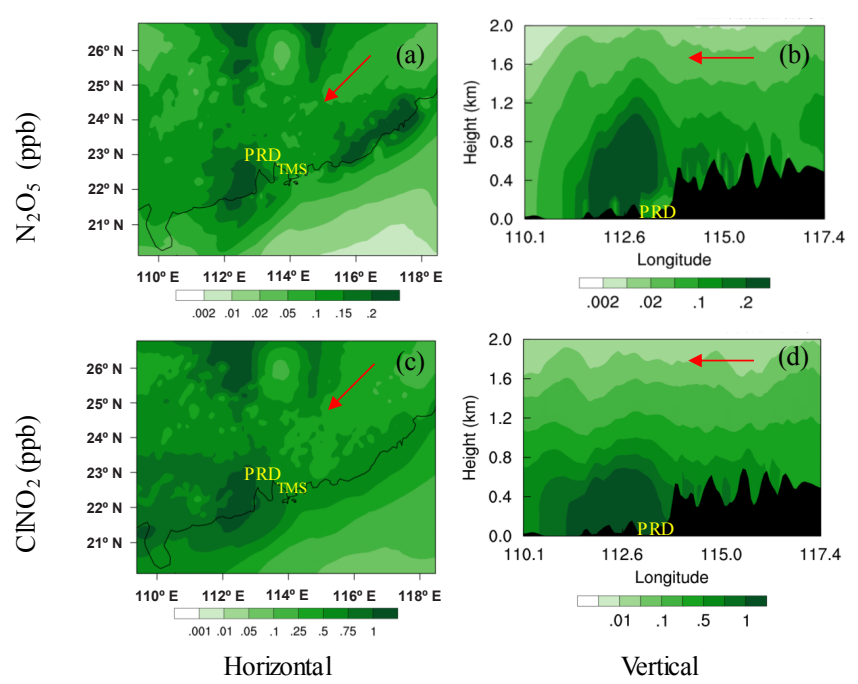

Figure 3. Horizontal distributions of (a) $\mathrm{N}_{2} \mathrm{O}_{5}$ and (c) $\mathrm{ClNO}_{2}$ average mixing ratios (ppb) during night-time (18:00-07:00 LT) within the $\mathrm{PBL}$ from the $\mathrm{HET}+\mathrm{Cl}$ case; vertical distributions of (b) $\mathrm{N}_{2} \mathrm{O}_{5}$ and (d) $\mathrm{ClNO}_{2}$ average mixing ratios (ppb) during nighttime (18:00-07:00 LT) in the domain intercepting PRD and along the prevailing wind direction from the $\mathrm{HET}+\mathrm{Cl}$ case. Red arrows represent the prevailing wind direction. The black shading in vertical plots represents terrain features.

\subsubsection{Spatial distribution of average simulated $\mathrm{N}_{2} \mathrm{O}_{5}$ and $\mathrm{ClNO}_{2}$}

Figure $3 \mathrm{a}$ and $\mathrm{c}$ show the average mixing ratios of $\mathrm{N}_{2} \mathrm{O}_{5}$ and $\mathrm{ClNO}_{2}$ during the night-time (18:00-07:00 LT) within the lowest $1000 \mathrm{~m}$ (the approximate height of the PBL at noon) in southern China in the HET $+\mathrm{Cl}$ case. Elevated levels of $\mathrm{N}_{2} \mathrm{O}_{5}(>0.10 \mathrm{ppb})$ and $\mathrm{ClNO}_{2}(>0.25 \mathrm{ppb})$ were predicted in the areas downwind of the PRD, as a result of the transport of pollutant enriched air masses towards the south-west of the PRD by the prevailing north-easterly winds. The areas with the highest simulated $\mathrm{N}_{2} \mathrm{O}_{5}$ and $\mathrm{ClNO}_{2}$ values did not cover the TMS site at which the highest ever reported $\mathrm{N}_{2} \mathrm{O}_{5}$ and $\mathrm{ClNO}_{2}$ values were observed (Brown et al., 2016; Wang et al., 2016), which supports our speculation that the locations downwind of the PRD under the dominant northeasterly winds may frequently have higher levels of $\mathrm{ClNO}_{2}$. The simulated yield of $\mathrm{ClNO}_{2}$ during the night-time ranged from 0.1 to 0.7 within the PBL (Fig. S4), which is consistent with a previous observation study $(0.1$ to 0.65 ; Osthoff et al., 2008) and modelling study (0.0 to 0.9; Sarwar et al., 2012).

The vertical distributions of $\mathrm{N}_{2} \mathrm{O}_{5}$ and $\mathrm{ClNO}_{2}$ in the vertical domain (as described in Sect. 2.3.1) are shown in Fig. $3 \mathrm{~b}$ and d. Elevated levels of $\mathrm{N}_{2} \mathrm{O}_{5}(>0.10 \mathrm{ppb})$ were predicted up to around $1000 \mathrm{~m}$ a.g.l., with the highest $\mathrm{N}_{2} \mathrm{O}_{5}$ level ( $>0.25 \mathrm{ppb}$ ) mostly between 400 and $800 \mathrm{~m}$ a.g.l., probably due to the reactions of $\mathrm{NO}_{3}$ with $\mathrm{NO}$ and VOCs in the lowest several hundred metres over the urban area, as 

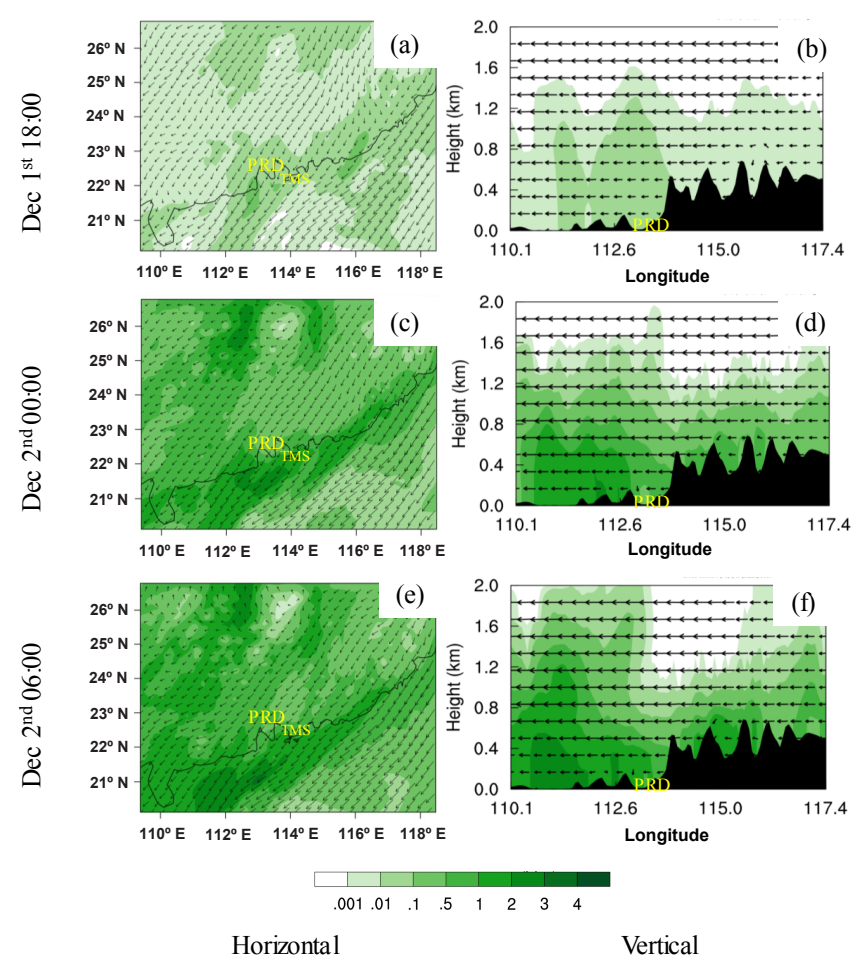

Figure 4. Horizontal distributions of $\mathrm{ClNO}_{2}$ concentrations (ppb) at (a) 18:00 LT on 1 December, (c) 00:00 LT on 2 December and (e) 06:00 LT on 2 December within the PBL from the HET $+\mathrm{Cl}$ case; vertical distributions of $\mathrm{ClNO}_{2}$ concentrations (ppb) at (b) 18:00 LT on 1 December, (d) 00:00 LT on 2 December and (f) 06:00 LT on 2 December in the domain intercepting PRD and along the prevailing wind direction from the $\mathrm{HET}+\mathrm{Cl}$ case.

shown in Fig. S5. Elevated levels of $\mathrm{ClNO}_{2}(>0.25 \mathrm{ppb})$ were simulated up to 1000 ma.g.l., with the highest $\mathrm{ClNO}_{2}$ values $(>1.00 \mathrm{ppb})$ mostly concentrated within the near-surface layer of $0-200 \mathrm{~m}$ a.g.l. The vertical distribution of $\mathrm{ClNO}_{2}$ was consistent with the vertical profile of chloride, as shown in Fig. S6. The simulated vertical distribution of $\mathrm{N}_{2} \mathrm{O}_{5}$ and $\mathrm{ClNO}_{2}$ are similar to those from previous observation and modelling studies. Stutz et al. (2004) calculated the steadystate $\mathrm{N}_{2} \mathrm{O}_{5}$ concentrations based on the measured vertical profile of $\mathrm{NO}_{2}$ and $\mathrm{NO}_{3}$, and they found elevated values (up to $300 \mathrm{ppt}$ ) aloft $(\sim 110 \mathrm{~m})$. Brown et al. (2007a) measured $\mathrm{N}_{2} \mathrm{O}_{5}$ vertical profile within the nocturnal boundary layer $(<300 \mathrm{~m})$ on a tower in Boulder, United States, and they found the peak value $(\sim 700 \mathrm{ppt})$ at $\sim 200 \mathrm{~m}$ a.g.l. Brown et al. (2007b) reported $\mathrm{N}_{2} \mathrm{O}_{5}$ vertical measurements from an aircraft in the United States, and the average results showed the peak concentrations $(\sim 160 \mathrm{ppt})$ at $\sim 200 \mathrm{~m}$ a.g.l. Sarwar et al. (2012) simulated the distributions of $\mathrm{N}_{2} \mathrm{O}_{5}$ and $\mathrm{ClNO}_{2}$ with CMAQ, and found that $\mathrm{N}_{2} \mathrm{O}_{5}$ peaked at 200$400 \mathrm{~m}$ a.g.l., and $\mathrm{ClNO}_{2}$ peaked at the surface and stretched up to $400 \mathrm{~m}$ a.g.l. in several US cities at dawn.

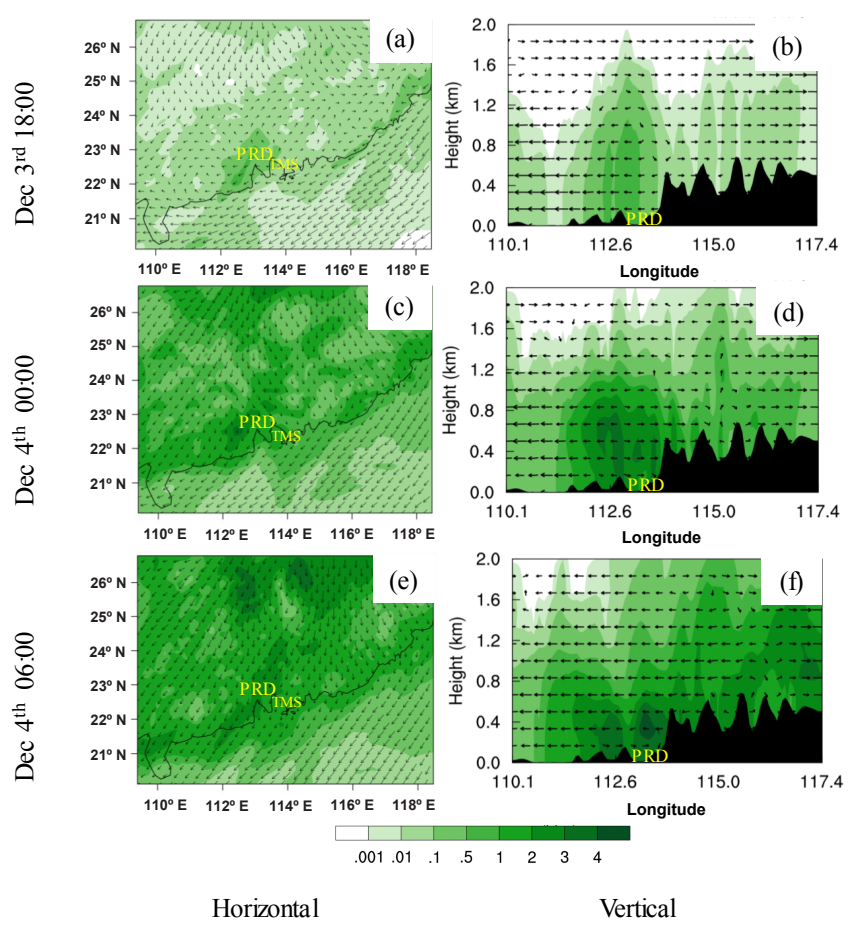

Figure 5. The same as in Fig. 4, except in the night of 3/4 December.

\subsubsection{Dynamic evolutions in cases with typical and extreme meteorological conditions}

We examine the time evolution of the spatial distribution of $\mathrm{ClNO}_{2}$ in two cases. In the typical case (the night of $1 / 2 \mathrm{De}-$ cember), southern China was dominated by consistent northeasterly winds which represented the average dynamic conditions during the study period, while in the extreme case (the night of 3/4 December), the air flow over the region abruptly changed. Note that in this extreme case, the highest ever reported $\mathrm{ClNO}_{2}$ levels were observed at the TMS site, and the back trajectories and observations of chemical species pointed to the transport to the site of well-processed plumes from the PRD with enriched anthropogenic chloride and other pollutants (Wang et al., 2016).

In the typical case, consistent north-easterly winds controlled southern China throughout the night (Fig. 4). At the beginning of the night (18:00 local time; $\mathrm{LT}), \mathrm{ClNO}_{2}$ began to build up near the urban area (Fig. 4a) and near the surface (Fig. 4b); at midnight (00:00 LT), the air with an elevated level of $\mathrm{ClNO}_{2}$ moved to coastal areas (Fig. 4c) and accumulated near the surface (Fig. 4d); at dawn (06:00 LT), the peak $\mathrm{ClNO}_{2}$ level was predicted over the open sea (Fig. 4e), and was pumped up to higher altitudes, with the peak value near the surface (Fig. 4f), due to the higher boundary layer height over the ocean, as shown in Fig. S7.

In the extreme case, at the beginning of the evening (18:00 LT), southern China had unfavourable dispersion conditions over the land, including inconsistent wind directions 
and low wind speeds. The air pollutants emitted from the PRD slowly swirled over it, as shown in Fig. 5a, resulting in a longer "cooking" time for $\mathrm{ClNO}_{2}$ production. The vertical distribution (Fig. 5b) shows that $\mathrm{ClNO}_{2}$-enriched air stretched from the ground up to $800 \mathrm{ma}$ a.g.l. The enhanced production of $\mathrm{ClNO}_{2}$ is believed to be partially responsible for the highest $\mathrm{ClNO}_{2}$ mixing ratios measured at the TMS site during that night. At midnight (00:00 LT), inconsistent wind directions were evident between land and sea areas: northerly winds dominated over the land area, while northeasterly winds dominated over the sea, leading to relatively slow motion of the $\mathrm{ClNO}_{2}$-enriched plume from the land towards the ocean (Fig. 5c). The vertical distribution (Fig. 5d) suggests that $\mathrm{ClNO}_{2}$ built up within the residue layer. At dawn (06:00 LT), the north-easterly wind regained control over the land areas, and the air with the elevated level of $\mathrm{ClNO}_{2}(>2.00 \mathrm{ppb})$ was driven towards the ocean, as shown in Fig. 5e. The vertical distribution (Fig. 5f) shows that the peak $\mathrm{ClNO}_{2}$ concentration was predicted to be in the residue layer at $\sim 300 \mathrm{~m}$ a.g.l. The changes of wind flow over the region during this night resulted in abnormal changes in the history of the air masses that reached the TMS site and led to the abrupt changes in the air pollutants concentrations observed there (see Wang et al., 2016, for details).

From these results, it can be seen that the vertical distributions of $\mathrm{ClNO}_{2}$ demonstrated distinct features in the two cases. To understand the underlying cause, it is of significance to measure the vertical profiles of $\mathrm{ClNO}_{2}$ under various meteorological conditions. In addition, during the extreme event, the location with the highest predicted $\mathrm{ClNO}_{2}$ $(>2.00 \mathrm{ppb})$ was not at the TMS site (>1.00 ppb), but it was located in the western parts of the PRD (i.e. the cities of Jiangmen and Zhaoqing), which supports the contention that the $\mathrm{ClNO}_{2}$ concentrations at other locations could be even higher than those observed at the TMS site (Wang et al., 2016). It would be of great interest to conduct measurements in the areas where the highest $\mathrm{ClNO}_{2}$ concentrations are predicted.

\subsection{Impacts of $\mathrm{N}_{2} \mathrm{O}_{5}$ heterogeneous uptake and $\mathrm{Cl}$ activation on $\mathrm{NO}_{x}$, total nitrate and $\mathrm{O}_{3}$}

\subsubsection{Impacts on horizontal and vertical distributions of the species}

Figure 6 shows the simulation results for the average NO, $\mathrm{NO}_{2}$, total nitrate and $\mathrm{O}_{3}$ concentrations within the PBL $(<1000 \mathrm{~m})$ during the entire simulation period in the base case, and the difference of the results between the HET $+\mathrm{Cl}$ and base cases in the horizontal domain. Relatively high levels of $\mathrm{NO}$ (up to $26.18 \mathrm{ppb}$; Fig. 6a), $\mathrm{NO}_{2}$ (up to $29.18 \mathrm{ppb}$; Fig. 6c), total nitrate (up to $23.43 \mu \mathrm{g} \mathrm{m}^{-3}$; Fig. 6e) and $\mathrm{O}_{3}$ (up to $44.50 \mathrm{ppb}$; Fig. $6 \mathrm{~g}$ ) were predicted in southern China in the base case. The spatial distributions of maxima of $\mathrm{NO}$ (Fig. S8a), $\mathrm{NO}_{2}$ (Fig. S8c) and total nitrate (Fig. S8e) were

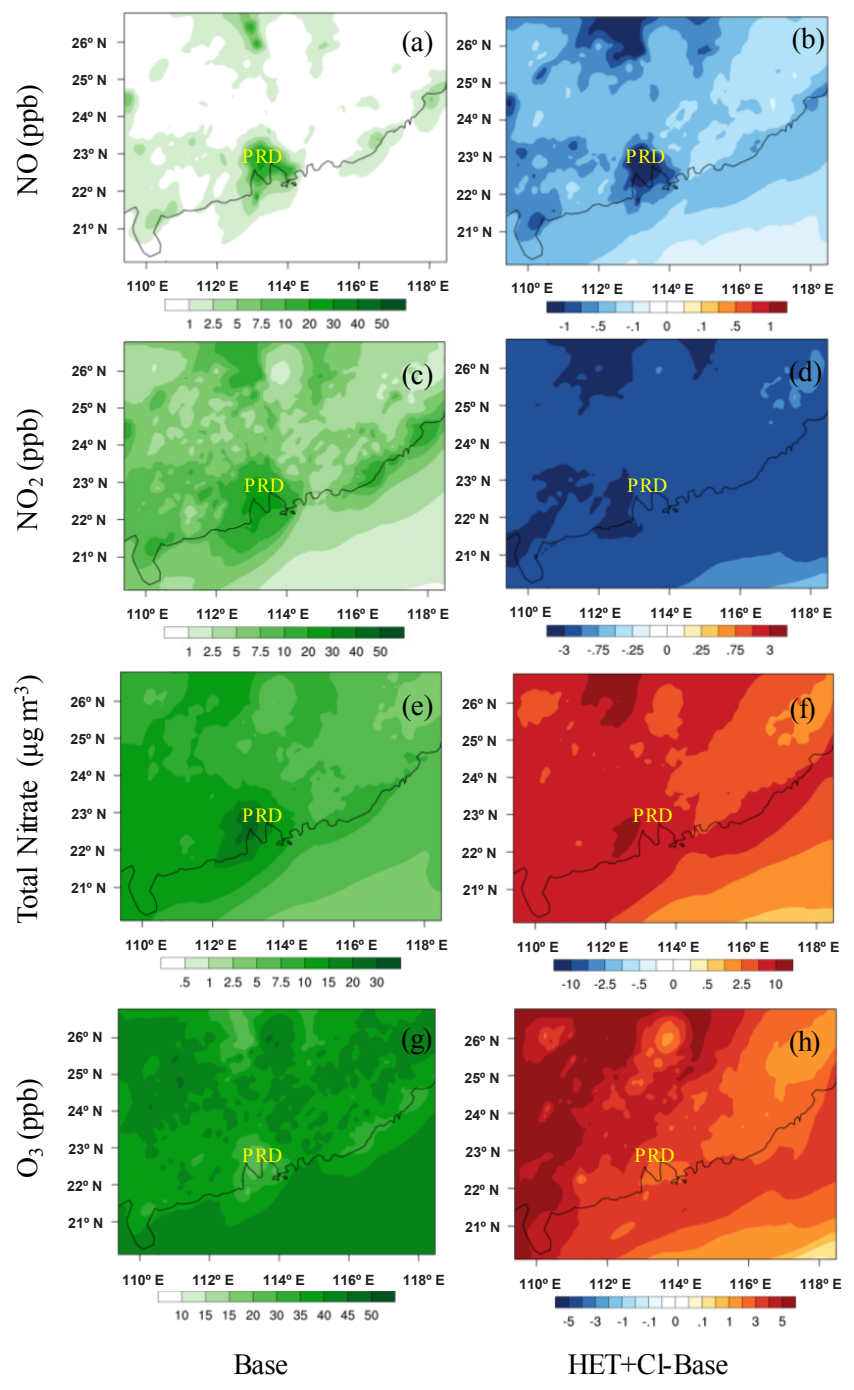

Figure 6. Horizontal distributions of (a) $\mathrm{NO}(\mathrm{ppb})$, (c) $\mathrm{NO}_{2}(\mathrm{ppb})$, (e) total nitrate $\left(\mu \mathrm{g} \mathrm{m}^{-3}\right)$ and $(\mathrm{g}) \mathrm{O}_{3}(\mathrm{ppb})$ average concentrations during the study period within the PBL from the base case; the average impacts of $\mathrm{N}_{2} \mathrm{O}_{5}$ uptake and $\mathrm{Cl}$ activation on (b) $\mathrm{NO}(\mathrm{ppb})$, (d) $\mathrm{NO}_{2}(\mathrm{ppb})$, (f) total nitrate $\left(\mu \mathrm{g} \mathrm{m}^{-3}\right)$ and (h) $\mathrm{O}_{3}(\mathrm{ppb})$ average concentrations during the simulation period in the horizontal domain within the PBL.

similar to those of their daily averages, whereas the spatial distribution of $1 \mathrm{~h}$ maxima $\mathrm{O}_{3}$ (higher in PRD and its downwind areas; Fig. S8g) was different from its daily average (higher in rural and remote region; Fig. 6g). With the prevailing north-easterly wind, the pollutants emitted from the PRD were transported towards the south-west, resulting in the most polluted regions being the PRD and its southwesterly downwind areas. After addition of the $\mathrm{N}_{2} \mathrm{O}_{5}$ uptake and $\mathrm{Cl}$ activation processes, the $\mathrm{NO}$ (Fig. 6b) and $\mathrm{NO}_{2}$ (Fig. 6d) levels were significantly decreased in the entire domain by up to $1.93 \mathrm{ppb}(\sim 7.4 \%)$ and $4.73 \mathrm{ppb}(\sim 16.2 \%)$, respectively. The regions with greater impacts on the NO 
and $\mathrm{NO}_{2}$ due to the added processes were mostly urban and suburban areas with large emissions of $\mathrm{NO}_{x}$. A significant portion of $\mathrm{NO}_{x}$ was transformed into total nitrate, which increased by as much as $13.45 \mu \mathrm{g} \mathrm{m}^{-3}(\sim 57.4 \%)$ through the heterogeneous uptake of $\mathrm{N}_{2} \mathrm{O}_{5}$ (see Fig. 6f). As can be seen in Fig. 6h, the $\mathrm{N}_{2} \mathrm{O}_{5}$ uptake and $\mathrm{Cl}$ activation noticeably increased the $\mathrm{O}_{3}$ levels across southern China, with a maximum increase up to $7.23 \mathrm{ppb}(\sim 16.3 \%)$. It is worth noting that in addition to the urban and suburban areas, the $\mathrm{O}_{3}$ levels over the rural and coastal areas were also significantly affected by the added processes. The average impacts of $\mathrm{N}_{2} \mathrm{O}_{5}$ uptake and $\mathrm{Cl}$ activation on daily maxima of $\mathrm{NO}, \mathrm{NO}_{2}$, total nitrate and $\mathrm{O}_{3}$ were shown in Fig. S8b, d, f and h, which had similar spatial patterns to the averaged results of the entire simulation period. The incorporation of $\mathrm{N}_{2} \mathrm{O}_{5}$ uptake and $\mathrm{Cl}$ activation improved the model performance for daily $\mathrm{O}_{3}$ and $1 \mathrm{~h}$ maximum $\mathrm{O}_{3}$ (Table 3), but it did not improve the simulations of $\mathrm{PM}_{2.5}$ and $\mathrm{NO}_{2}$, which could be due to various reasons, e.g. emission inventory.

Figure 7 shows the average simulated $\mathrm{NO}, \mathrm{NO}_{2}$, total nitrate and $\mathrm{O}_{3}$ values in the base case, and it shows the difference in the results between the base and $\mathrm{HET}+\mathrm{Cl}$ cases in the vertical domain. $\mathrm{NO}$ and $\mathrm{NO}_{2}$ were concentrated within $800 \mathrm{~m}$ a.g.l. over the PRD and in downwind areas (see Fig. $7 \mathrm{a}$ and c). Total nitrate accumulated near the ground and stretched up to $800 \mathrm{~m}$ a.g.l. (Fig. 7e). Due to the titration effect of $\mathrm{NO}$, relatively low average values of $\mathrm{O}_{3}$ were simulated over urban areas (Fig. 7g). As shown in Fig. 7b and d, the $\mathrm{N}_{2} \mathrm{O}_{5}$ uptake and $\mathrm{Cl}$ activation decreased the $\mathrm{NO}$ and $\mathrm{NO}_{2}$ levels across the vertical domain, with the largest impacts seen in the near-surface layer $(0-400 \mathrm{~m}$ a.g.l.) over the PRD. The lost $\mathrm{NO}$ and $\mathrm{NO}_{2}$ were mostly transformed into total nitrate, which increased remarkably in the near-surface layer (Fig. 7f). The impacts of $\mathrm{N}_{2} \mathrm{O}_{5}$ uptake and $\mathrm{Cl}$ activation on the $\mathrm{O}_{3}$ level varied with altitude: the $\mathrm{O}_{3}$ increased throughout the lowest $800 \mathrm{~m}$ with the largest enhancement near the ground, whereas it decreased above $1000 \mathrm{~m}$ a.g.l. (Fig. 7h). The changes in the $\mathrm{O}_{3}$ concentrations were attributed to the combined effects of $\mathrm{NO}_{x}$ loss due to $\mathrm{N}_{2} \mathrm{O}_{5}$ uptake and $\mathrm{Cl}$ atom production due to $\mathrm{Cl}$ activation, both of which have non-linear impacts on $\mathrm{O}_{3}$ production. The relative contribution of $\mathrm{N}_{2} \mathrm{O}_{5}$ uptake vs. $\mathrm{Cl}$ activation on the $\mathrm{NO}$, $\mathrm{NO}_{2}$, total nitrate and $\mathrm{O}_{3}$ concentrations will be discussed in the following section.

\subsubsection{Relative contribution of $\mathrm{N}_{2} \mathrm{O}_{5}$ heterogeneous uptake vs. $\mathrm{Cl}$ activation}

To understand the relative contribution of $\mathrm{N}_{2} \mathrm{O}_{5}$ uptake and $\mathrm{Cl}$ activation, we conducted a sensitivity case (HET case as listed in Table 2) in which only nitrate was produced via $\mathrm{N}_{2} \mathrm{O}_{5}$ uptake. The differences in the simulations between the base and HET cases represent the effects of $\mathrm{N}_{2} \mathrm{O}_{5}$ uptake, while those between the HET and HET $+\mathrm{Cl}$ cases represent the effects of $\mathrm{Cl}$ activation.
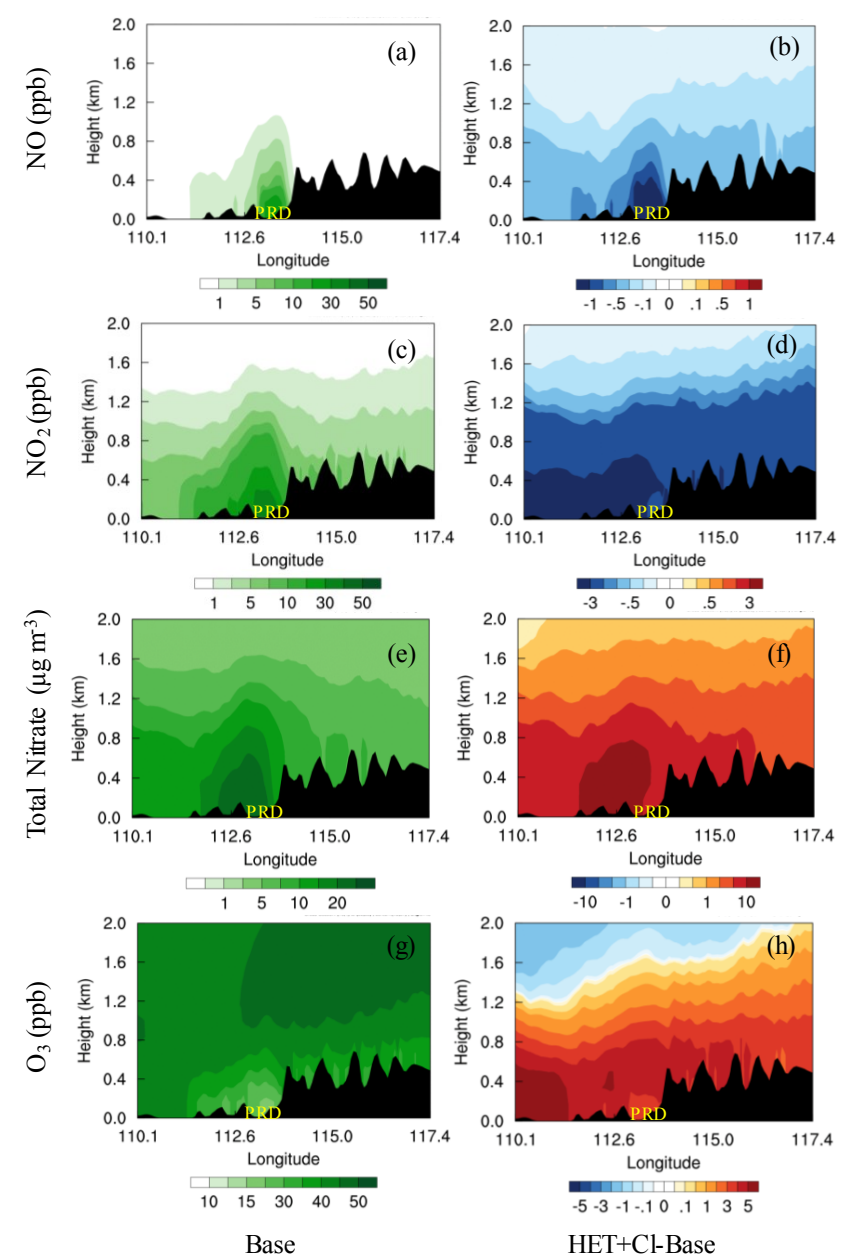

Figure 7. Vertical distributions of (a) $\mathrm{NO}$ (ppb), (c) $\mathrm{NO}_{2}(\mathrm{ppb})$, (e) total nitrate $\left(\mu \mathrm{g} \mathrm{m}^{-3}\right)$ and $(\mathrm{g}) \mathrm{O}_{3}(\mathrm{ppb})$ average concentrations during the study period in the domain intercepting PRD and along the prevailing wind from the base case; the average impacts of $\mathrm{N}_{2} \mathrm{O}_{5}$ uptake and $\mathrm{Cl}$ activation on (b) $\mathrm{NO}(\mathrm{ppb})$, (d) $\mathrm{NO}_{2}(\mathrm{ppb})$, (f) total nitrate $\left(\mu \mathrm{g} \mathrm{m}^{-3}\right)$ and (h) $\mathrm{O}_{3}(\mathrm{ppb})$ average concentrations during the simulation period in the vertical domain.

As shown in Fig. 8a and c, the mere consideration of nitrate production from $\mathrm{N}_{2} \mathrm{O}_{5}$ uptake led to decreases in NO and $\mathrm{NO}_{2}$ by up to 1.11 and $4.28 \mathrm{ppb}$, respectively. In addition, most of the lost $\mathrm{NO}_{x}$ was transformed into total nitrate, which increased by as much as $14.92 \mu \mathrm{g} \mathrm{m}^{-3}$ (Fig. 8e). These results are similar to those of Lowe et al. (2015), who suggested that the nitrate in $\mathrm{PM}_{10}$ was enhanced by up to $31.4 \%$ (increasing from 3.5 to $4.6 \mu \mathrm{g} \mathrm{kg}^{-1}$ at night) after considering the heterogeneous uptake processes of $\mathrm{N}_{2} \mathrm{O}_{5}$. The $\mathrm{N}_{2} \mathrm{O}_{5}$ uptake increased the $\mathrm{O}_{3}$ levels by as much as $3.10 \mathrm{ppb}$ in both urban and rural areas in the PRD and decreased the $\mathrm{O}_{3}$ by up to $1.47 \mathrm{ppb}$ in remote areas (Fig. 8g), which are similar to the findings of Riemer et al. (2003), which indicated that the $\mathrm{N}_{2} \mathrm{O}_{5}$ uptake resulted in an increase in the $\mathrm{O}_{3}$ level in high- $\mathrm{NO}_{x}$ areas and a decrease in low- $\mathrm{NO}_{x}$ areas. 

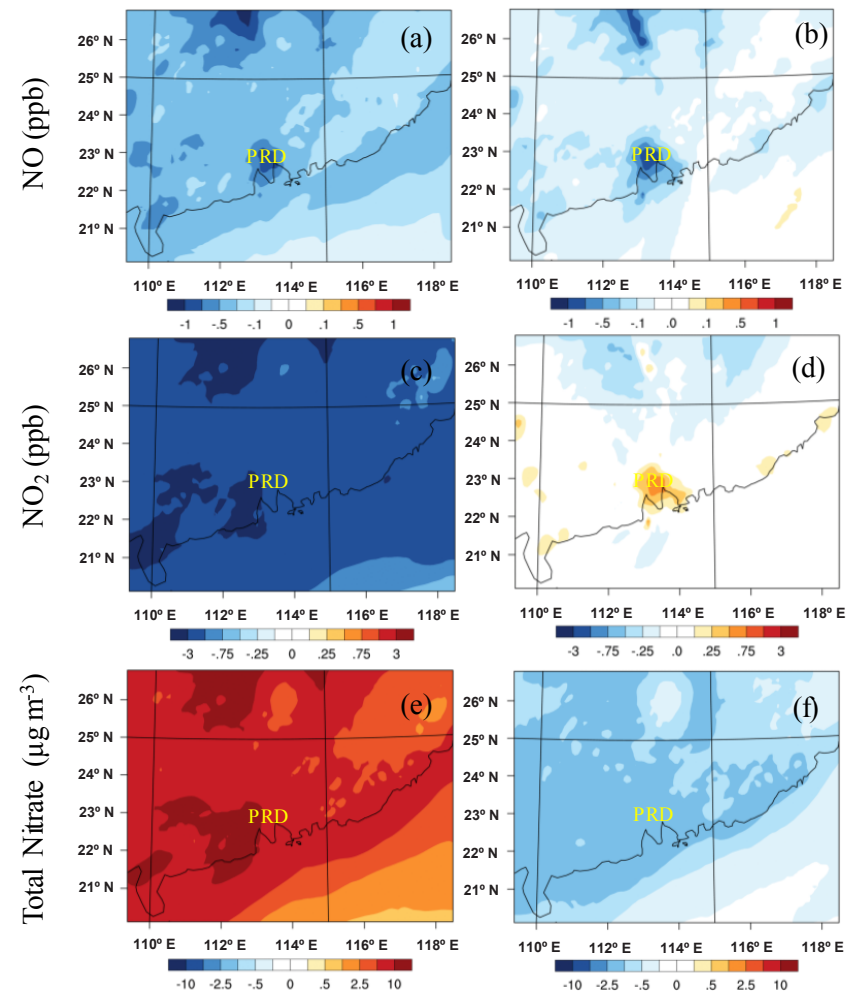

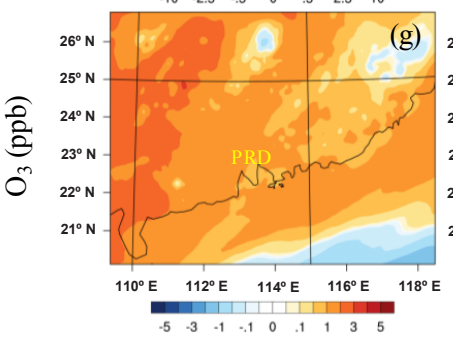

HET-Base

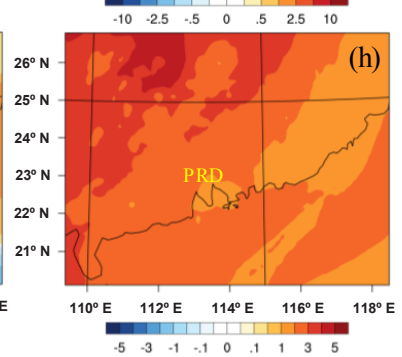

$\mathrm{HET}+\mathrm{Cl}-\mathrm{HET}$
Figure 8. Average impacts of $\mathrm{N}_{2} \mathrm{O}_{5}$ heterogeneous uptake on (a) $\mathrm{NO}(\mathrm{ppb})$, (c) $\mathrm{NO}_{2}(\mathrm{ppb})$, (e) total nitrate $\left(\mu \mathrm{g} \mathrm{m}^{-3}\right)$ and (g) $\mathrm{O}_{3}$ (ppb) average concentrations during the simulation period in the horizontal domain within the PBL; average impacts of $\mathrm{Cl}$ activation on (b) $\mathrm{NO}(\mathrm{ppb}),(\mathbf{d}) \mathrm{NO}_{2}(\mathrm{ppb})$, (f) total nitrate $\left(\mu \mathrm{g} \mathrm{m}^{-3}\right)$ and (h) $\mathrm{O}_{3}$ (ppb) average concentrations during the simulation period in the horizontal domain within the PBL.

The $\mathrm{Cl}$ activation decreased the total nitrate by up to $2.35 \mu^{-3} \mathrm{~m}^{-3}$ (Fig. 8f) because a fraction of $\mathrm{N}_{2} \mathrm{O}_{5}$ was consumed to produce $\mathrm{ClNO}_{2}$ in competition with nitrate production. The simulated $\mathrm{O}_{3}$ was significantly increased throughout the domain by as much as $4.54 \mathrm{ppb}$ (Fig. $8 \mathrm{~h}$ ), which could be attributed to the release of $\mathrm{NO}_{2}$ molecules that subsequently undergo photolysis and form $\mathrm{O}_{3}$, and the effects of the activation of $\mathrm{Cl}$ radicals that initiate VOCs degradation and $\mathrm{O}_{3}$ formation (Simon et al., 2009). The increase in the $\mathrm{O}_{3}$ further enhanced the oxidation of $\mathrm{NO}$ into $\mathrm{NO}_{2}$, which decreased NO by as much as $0.96 \mathrm{ppb}$ (Fig. $8 \mathrm{~b}$ ) and increased $\mathrm{NO}_{2}$ in urban areas by up to $0.72 \mathrm{ppb}$ (Fig. 8d). The recycling
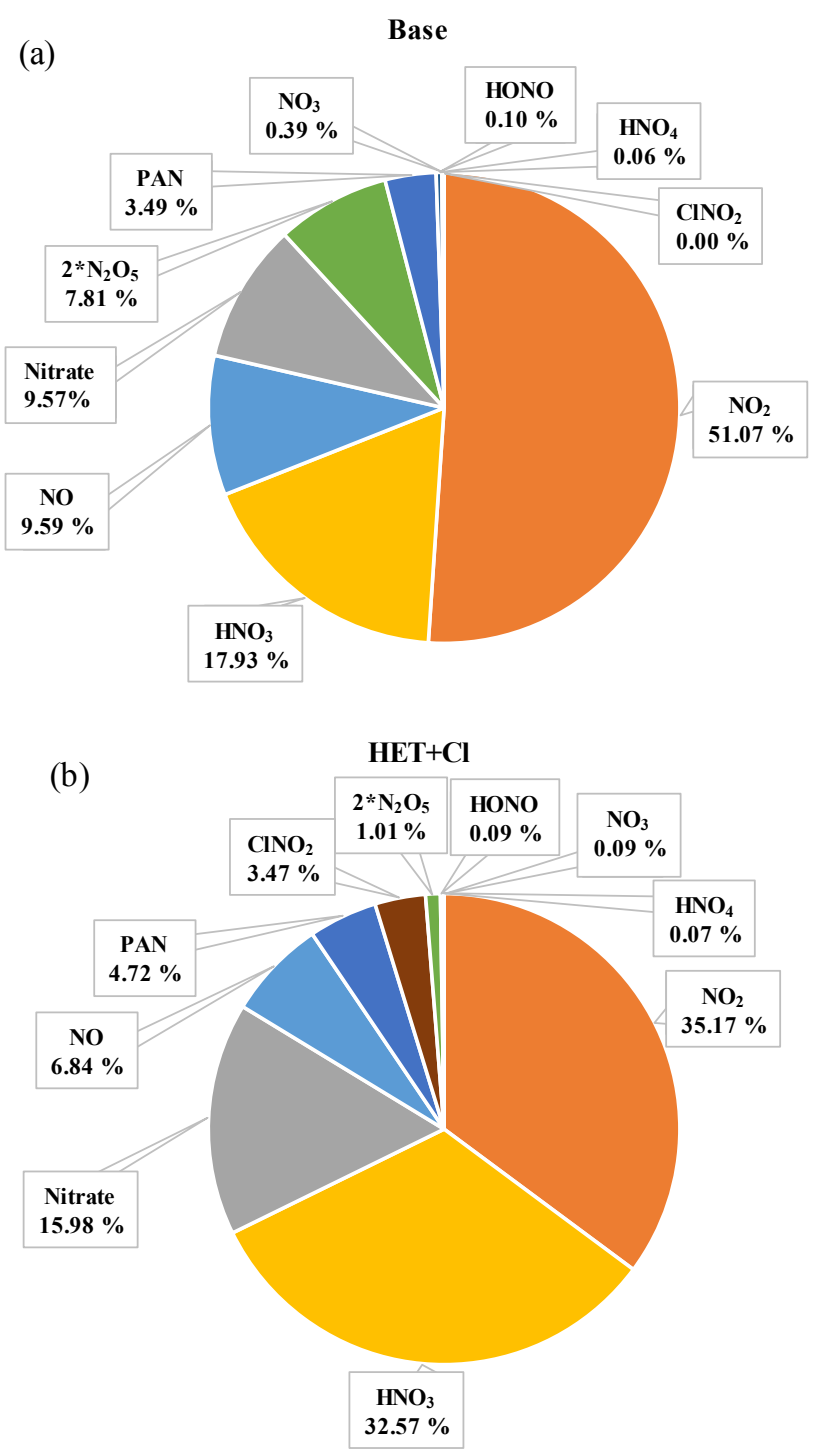

Figure 9. Average $\mathrm{NO}_{y}$ partitioning during the study period in southern China within the PBL as simulated in (a) the base case and (b) the $\mathrm{HET}+\mathrm{Cl}$ case.

of $\mathrm{NO}_{2}$ via $\mathrm{ClNO}_{2}$ photolysis also contributed to the increase in $\mathrm{NO}_{2}$. The $\mathrm{O}_{3}$ increase also elevated the $\mathrm{OH}$ radical levels, which enhanced the loss of $\mathrm{NO}_{2}$ through its reaction with $\mathrm{OH}$, resulting in the decrease of $\mathrm{NO}_{2}$ in suburban and rural regions by up to $0.53 \mathrm{ppb}$ (Fig. $8 \mathrm{~d}$ ).

\subsection{Impacts of $\mathrm{N}_{2} \mathrm{O}_{5}$ uptake and $\mathrm{Cl}$ activation on $\mathrm{NO}_{y}$ partitioning}

The composition and partitioning of $\mathrm{NO}_{y}$ affect the spatial range that nitrogenous species can reach after emission, and they are therefore of great importance in atmospheric chemistry (Bertram et al., 2013). The average concentration of $\mathrm{NO}_{y}$ changed modestly within the PBL over domain 2 with the addition of $\mathrm{N}_{2} \mathrm{O}_{5}$ uptake and $\mathrm{Cl}$ activation (12.24 and 


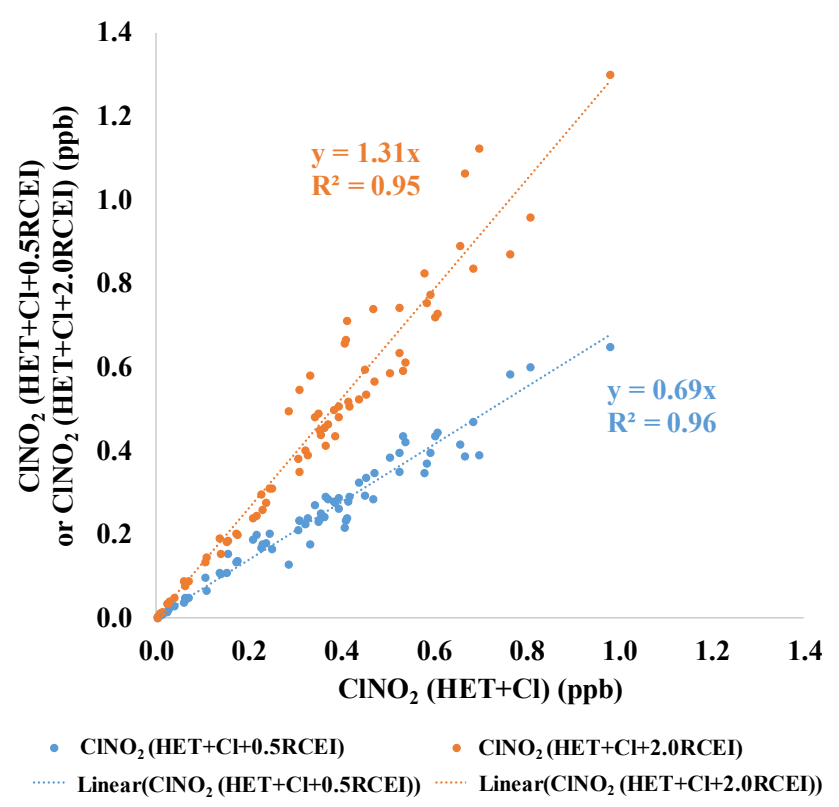

Figure 10. Scatter plots of $\mathrm{ClNO}_{2}$ (ppb) from simulations with half $(\mathrm{HET}+\mathrm{Cl}+0.5 \mathrm{RCEI})$ and twice $(\mathrm{HET}+\mathrm{Cl}+2.0 \mathrm{RCEI}) \mathrm{RCEI}$ emissions against $\mathrm{ClNO}_{2}$ (ppb) from simulations with original RCEI emissions $(\mathrm{HET}+\mathrm{Cl})$.

$11.42 \mathrm{ppb}$ in the base and $\mathrm{HET}+\mathrm{Cl}$ cases, respectively). The fractions of each species in $\mathrm{NO}_{y}$, however, were substantially affected. The $\mathrm{NO}_{y}$ partition was calculated over domain 2 for the base and $\mathrm{HET}+\mathrm{Cl}$ cases (see Fig. 9). The percentage of $\mathrm{N}_{2} \mathrm{O}_{5}$ in $\mathrm{NO}_{y}$ decreased from $7.80 \%$ in the base case to $1.01 \%$ in the $\mathrm{HET}+\mathrm{Cl}$ case, and that for $\mathrm{NO}_{3}$ decreased from 0.38 to $0.09 \%$. The $\mathrm{N}_{2} \mathrm{O}_{5}$ uptake and $\mathrm{Cl}$ activation reduced the fraction of $\mathrm{NO}$ from 9.59 to $6.84 \%$ and that of $\mathrm{NO}_{2}$ from 51.07 to $35.17 \%$. The percentage of total nitrate (nitrate + $\mathrm{HNO}_{3}$ ) in $\mathrm{NO}_{y}$ was significantly increased from 27.5 (i.e. $9.6 \%+17.9 \%$ ) to $48.6 \%$ (i.e. $16.0 \%+32.6 \%$ ). The added processes also introduced a new $\mathrm{NO}_{y}$ species, $\mathrm{ClNO}_{2}$, which accounted for $3.47 \%$ in the HET $+\mathrm{Cl}$ case. The decrease in the $\mathrm{NO}_{3}$ level caused by $\mathrm{N}_{2} \mathrm{O}_{5}$ heterogeneous uptake would suppress the night-time chemistry of $\mathrm{NO}_{3}$ and VOCs. The $\mathrm{N}_{2} \mathrm{O}_{5}$ uptake transferred a significant portion of $\mathrm{NO}_{x}$ to total nitrate, reducing the lifetime and the reaching range of $\mathrm{NO}_{x}$ enriched plumes and thus affecting the $\mathrm{NO}_{x}-\mathrm{VOCs}-\mathrm{O}_{3}$ photochemistry. The new species in the HET $+\mathrm{Cl}$ case, $\mathrm{ClNO}_{2}$, contributed a non-negligible part of $\mathrm{NO}_{y}$ and extended the lifetime and reaching range of reactive nitrogen.

\subsection{Sensitivity of $\mathrm{CINO}_{2}$ concentration to chlorine emission}

The production of $\mathrm{ClNO}_{2}$ depends on the chloride concentration in aerosol according to the parameterisation used in this study (Bertram and Thornton, 2009). The only available chlorine EI for China is taken from a global dataset with a relatively low resolution $\left(1^{\circ} \times 1^{\circ}\right)$ and for the year of 1990 (Keene et al., 1999). To test the sensitivity of the $\mathrm{ClNO}_{2}$ production to $\mathrm{Cl}$ emissions, we conducted two simulations in which the RCEI emissions were reduced by half $(\mathrm{HET}+\mathrm{Cl}+0.5 \mathrm{RCEI})$ and doubled $(\mathrm{HET}+\mathrm{Cl}+2.0 \mathrm{RCEI})$. The simulations show that the ambient chloride concentrations responded almost linearly to the applied chlorine emissions (data not shown). The simulated $\mathrm{ClNO}_{2}$ has a similar temporal pattern in different $\mathrm{Cl}$ emissions (Fig. S9). The $\mathrm{ClNO}_{2}$ concentrations have positive but not linear correlation with $\mathrm{Cl}$ emission changes. As shown in Fig. 10, halving the $\mathrm{Cl}$ emissions leads to a $31 \%$ reduction in the simulated $\mathrm{ClNO}_{2}$ level, whereas doubling the $\mathrm{Cl}$ emissions results in an average $31 \%$ increase of $\mathrm{ClNO}_{2}$. The results indicate that simulation of $\mathrm{ClNO}_{2}$ production is sensitive to chlorine emission. Therefore, future studies are needed to develop an up-to-date anthropogenic chlorine EI in China to better model $\mathrm{ClNO}_{2}$ production and to quantify its impact on atmospheric chemistry and air quality. Previous research on chlorine emission could be used as a reference to develop a chlorine EI in China. Chang et al. (2002) compiled a chlorine EI for Houston including the emissions from cooling towers, sea salt, point sources and various water treatments. Sarwar and Bhave (2007) integrated a chlorine EI for the eastern United States with sources of various industrial point sources, area sources, cooling towers and swimming pools.

\section{Summary and conclusions}

In this study, a state-of-the-art chemical transport model (WRF-Chem) was further developed by incorporation of a widely used aerosol thermodynamics model (ISORROPIA II), parameterisation of heterogeneous uptake of $\mathrm{N}_{2} \mathrm{O}_{5}$ and $\mathrm{ClNO}_{2}$ production and gas-phase chlorine chemistry. The revised model was used to simulate the spatial distributions of $\mathrm{N}_{2} \mathrm{O}_{5}$ and $\mathrm{ClNO}_{2}$ and the impacts on $\mathrm{O}_{3}$ and $\mathrm{NO}_{y}$ partitioning over the HK-PRD region where high levels of $\mathrm{N}_{2} \mathrm{O}_{5}$ and $\mathrm{ClNO}_{2}$ had been observed. The revised model was able to capture the temporal patterns and the magnitudes of the observed $\mathrm{N}_{2} \mathrm{O}_{5}$ and $\mathrm{ClNO}_{2}$ at a mountaintop site in Hong Kong, but it tended to underpredict $\mathrm{N}_{2} \mathrm{O}_{5}$ and overpredict $\mathrm{ClNO}_{2}$ because of the underestimates of $\mathrm{N}_{2} \mathrm{O}_{5}$ sources and overestimates of $\mathrm{N}_{2} \mathrm{O}_{5}$ sink and $\mathrm{ClNO}_{2}$ production. Model simulations show that under average conditions, high values of $\mathrm{N}_{2} \mathrm{O}_{5}$ and $\mathrm{ClNO}_{2}$ are concentrated in the region southwest of the urban areas of the PRD and vertically peak within the layer of 400-800 and 0-200 m a.g.l, respectively. In the night of 3/4 December when the highest ever reported $\mathrm{ClNO}_{2}(4.7 \mathrm{ppb})$ was observed, the model suggested that the high levels of $\mathrm{ClNO}_{2}$ were concentrated in the residue layer ( $\sim 300 \mathrm{~m}$ a.g.l.) above the study region. The model simulations suggested that the region downwind of the urban PRD may experience higher levels of $\mathrm{ClNO}_{2}$ than those observed at the TMS site. $\mathrm{N}_{2} \mathrm{O}_{5}$ uptake and $\mathrm{Cl}$ activation significantly 
decreased the levels of $\mathrm{NO}$ and $\mathrm{NO}_{2}$ by up to $1.93(\sim 7.4 \%)$ and $4.73 \mathrm{ppb}(\sim 16.2 \%)$, respectively, but they increased the total nitrate level by as much as $13.45 \mu \mathrm{g} \mathrm{m}^{-3}(\sim 57.4 \%)$ and the $\mathrm{O}_{3}$ by up to $7.23 \mathrm{ppb}(\sim 16.3 \%)$ within the PBL. Our results demonstrate the significant impacts of $\mathrm{N}_{2} \mathrm{O}_{5}$ uptake and $\mathrm{ClNO}_{2}$ production on $\mathrm{NO}_{x}$ lifetime, secondary nitrate production and $\mathrm{O}_{3}$ formation, and they underscore the necessity of considering these processes in air quality models. Our simulations of $\mathrm{ClNO}_{2}$ levels over southern China are sensitive to chlorine emissions, which suggests the need to develop a more reliable emission inventory of chlorine for better quantification of $\mathrm{N}_{2} \mathrm{O}_{5} / \mathrm{ClNO}_{2}$ chemistry and its impacts over China.

Both the data and source code of the revised model used in this study are available upon request from the corresponding author (cetwang@polyu.edu.hk).

\section{The Supplement related to this article is available online at doi:10.5194/acp-16-14875-2016-supplement.}

Acknowledgements. The authors would like to thank the China National Meteorological Center and the Hong Kong Observatory for providing the meteorological data and the Hong Kong Environmental Protection Department for providing the routine air pollutants measurement data and the emission inventory in Hong Kong. This study is supported by a Hong Kong Polytechnic University PhD studentship, the General Research Fund of the Hong Kong Research Grants Council (PolyU 153026/14P) and the Collaborative Research Fund of the Hong Kong Research Grants Council (C5022-14G).

Edited by: J. Roberts

Reviewed by: two anonymous referees

\section{References}

Ahmadov, R., McKeen, S. A., Robinson, A. L., Bahreini, R., Middlebrook, A. M., Gouw, J. D., Meagher, J., Hsie, E. Y., Edgerton, E., Shaw, S., and Trainer, M.: A volatility basis set model for summertime secondary organic aerosols over the eastern United States in 2006, J. Geophys. Res.-Atmos., 117, D06301, doi:10.1029/2011JD016831, 2012.

Anttila, T., Kiendler-Scharr, A., Tillmann, R., and Mentel, T. F.: On the reactive uptake of gaseous compounds by organic-coated aqueous aerosols: Theoretical analysis and application to the heterogeneous hydrolysis of $\mathrm{N}_{2} \mathrm{O}_{5}$, J. Phys. Chem. A, 110, 1043510443, 2006.

Archer-Nicholls, S., Lowe, D., Utembe, S., Allan, J., Zaveri, R. A., Fast, J. D., Hodnebrog, Ø., Denier van der Gon, H., and McFiggans, G.: Gaseous chemistry and aerosol mechanism developments for version 3.5.1 of the online regional model, WRFChem, Geosci. Model Dev., 7, 2557-2579, doi:10.5194/gmd-72557-2014, 2014.
Atkinson, R.: Atmospheric chemistry of VOCs and $\mathrm{NO}_{x}$, Atmos. Environ., 34, 2063-2101, 2000.

Atkinson, R., Baulch, D. L., Cox, R. A., Crowley, J. N., Hampson, R. F., Hynes, R. G., Jenkin, M. E., Rossi, M. J., and Troe, J.: Evaluated kinetic and photochemical data for atmospheric chemistry: Volume III - gas phase reactions of inorganic halogens, Atmos. Chem. Phys., 7, 981-1191, doi:10.5194/acp-7-981-2007, 2007.

Atkinson, R., Baulch, D. L., Cox, R. A., Crowley, J. N., Hampson, R. F., Hynes, R. G., Jenkin, M. E., Rossi, M. J., Troe, J., and Wallington, T. J.: Evaluated kinetic and photochemical data for atmospheric chemistry: Volume IV - gas phase reactions of organic halogen species, Atmos. Chem. Phys., 8, 4141-4496, doi:10.5194/acp-8-4141-2008, 2008.

Bertram, T. H. and Thornton, J. A.: Toward a general parameterization of $\mathrm{N}_{2} \mathrm{O}_{5}$ reactivity on aqueous particles: the competing effects of particle liquid water, nitrate and chloride, Atmos. Chem. Phys., 9, 8351-8363, doi:10.5194/acp-9-8351-2009, 2009.

Bertram, T. H., Perring, A. E., Wooldridge, P. J., Dibb, J., Avery, M. A., and Cohen, R. C.: On the export of reactive nitrogen from Asia: $\mathrm{NO}_{x}$ partitioning and effects on ozone, Atmos. Chem Phys., 13, 4617-4630, doi:10.5194/acp-13-4617-2013, 2013.

Brown, S. S., Ryerson, T. B., Wollny, A. G., Brock, C. A., Peltier, R., Sullivan, A. P., Weber, R. J., Dube, W. P., Trainer, M., Meagher, J. F., Fehsenfeld, F. C., and Ravishankara, A. R.: Variability in nocturnal nitrogen oxide processing and its role in regional air quality, Science, 311, 67-70, 2006.

Brown, S. S., Dubé, W. P., Osthoff, H. D., Wolfe, D. E., Angevine, W. M., and Ravishankara, A. R.: High resolution vertical distributions of NO3 and N2O5 through the nocturnal boundary layer, Atmos. Chem. Phys., 7, 139-149, doi:10.5194/acp-7-139-2007, 2007a.

Brown, S. S., Dubé, W. P., Osthoff, H. D., Stutz, J., Ryerson, T. B., Wollny, A. G., Brock, C. A., Warneke, C., de Gouw, J. A., Atlas, E., Neuman, J. A., Holloway, J. S., Lerner, B. M., Williams, E. J., Kuster, W. C., Goldan, P. D., Angevine, W. M., Trainer, M., Fehsenfeld, F. C., and Ravishankara, A. R.: Vertical profiles in $\mathrm{NO}_{3}$ and $\mathrm{N}_{2} \mathrm{O}_{5}$ measured from an aircraft: Results from the NOAA and surface platforms during the New England Air Quality Study 2004, J. Geophys. Res.-Atmos., 112, D22304, doi:10.1029/2007JD008883, 2007b.

Brown, S. S., Dube, W. P., Fuchs, H., Ryerson, T. B., Wollny, A. G., Brock, C. A., Bahreini, R., Middlebrook, A. M., Neuman, J. A., Atlas, E., Roberts, J. M., Osthoff, H. D., Trainer, M., Fehsenfeld, F. C., and Ravishankara, A. R.: Reactive uptake coefficients for $\mathrm{N}_{2} \mathrm{O}_{5}$ determined from aircraft measurements during the Second Texas Air Quality Study: Comparison to current model parameterizations, J. Geophys. Res.-Atmos., 114, D00F10, doi:10.1029/2008JD011679, 2009.

Brown, S. S. and Stutz, J.: Nighttime radical observations and chemistry, Chem. Soc. Rev., 41, 6405-6447, 2012.

Brown, S. S., Dubé, W. P., Tham, Y. J., Zha, Q., Xue, L., Poon, S., Wang, Z., Blake, D. R., Tsui, W., Parrish, D. D., and Wang, T.: Nighttime chemistry at a high altitude site above Hong Kong, J. Geophys. Res.-Atmos., 121, 2457-2475, doi:10.1002/2015JD024566, 2016.

Chang, S., McDonald-Buller, E., Kimura, Y., Yarwood, G., Neece, J., Russell, M., Tanaka, P., and Allen, D.: Sensitivity of urban ozone formation to chlorine emission estimates, Atmos. Environ., 36, 4991-5003, 2002. 
Chang, W. L., Bhave, P. V., Brown, S. S., Riemer, N., Stutz, J., and Dabdub, D.: Heterogeneous atmospheric chemistry, ambient measurements, and model calculations of $\mathrm{N}_{2} \mathrm{O}_{5}$ : A review, Aerosol Sci. Technol., 45, 665-695, 2011.

Chen, F. and Dudhia, J.: Coupling an advanced land surfacehydrology model with the Penn State-NCAR MM5 modeling system, Part I: Model implementation and sensitivity, Mon. Weather Rev., 129, 569-585, 2001.

Davis, J. M., Bhave, P. V., and Foley, K. M.: Parameterization of $\mathrm{N}_{2} \mathrm{O}_{5}$ reaction probabilities on the surface of particles containing ammonium, sulfate, and nitrate, Atmos. Chem. Phys., 8, 52955311, doi:10.5194/acp-8-5295-2008, 2008.

Dentener, F. J. and Crutzen, P. J.: Reaction of $\mathrm{N}_{2} \mathrm{O}_{5}$ on tropospheric aerosols: Impact on the global distributions of $\mathrm{NO}_{x}, \mathrm{O}_{3}$, and $\mathrm{OH}$, J. Geophys. Res.-Atmos., 98, 7149-7163, 1993.

Evans, M. J. and Jacob, D. J.: Impact of new laboratory studies of $\mathrm{N}_{2} \mathrm{O}_{5}$ hydrolysis on global model budgets of tropospheric nitrogen oxides, ozone, and OH, Geophys. Res. Lett., 32, L09813, doi:10.1029/2005GL022469, 2005.

Finlayson-Pitts, B. J., Ezell, M. J., and Pitts, J. N.: Formation of chemically active chlorine compounds by reactions of atmospheric $\mathrm{NaCl}$ particles with gaseous $\mathrm{N}_{2} \mathrm{O}_{5}$ and $\mathrm{ClONO}_{2}$, Nature, $337,241-244,1989$.

Fountoukis, C. and Nenes, A.: ISORROPIA II: a computationally efficient thermodynamic equilibrium model for $\mathrm{K}^{+}-\mathrm{Ca}^{2+}$ $\mathrm{Mg}^{2+}-\mathrm{NH}^{4+}-\mathrm{Na}^{+}-\mathrm{SO}_{4}^{2-}-\mathrm{NO}_{3}^{-}-\mathrm{Cl}^{-}-\mathrm{H}_{2} \mathrm{O}$ aerosols, Atmos. Chem. Phys., 7, 4639-4659, doi:10.5194/acp-7-4639-2007, 2007.

Gong, S. L., Barrie, L. A., and Lazare, M.: Canadian Aerosol Module (CAM): A size-segregated simulation of atmospheric aerosol processes for climate and air quality models: 2 . Global sea-salt aerosol and its budgets, J. Geophys. Res.-Atmos., 107, D24, 4779, doi:10.1029/2001JD002004, 2002.

Grell, G. A. and Dévényi, D.: A generalized approach to parameterizing convection combining ensemble and data assimilation techniques, Geophys. Res. Lett., 29, 1693, doi:10.1029/2002GL015311, 2002.

Grell, G. A., Peckham, S. E., Schmitz, R., McKeen, S. A., Frost, G., Skamarock, W. C., and Eder, B.: Fully coupled "online" chemistry within the WRF model, Atmos. Environ., 39, 6957-6975, 2005.

Guenther, A., Zimmerman, P., and Wildermuth, M.: Natural volatile organic compound emission rate estimates for US woodland landscapes, Atmos. Environ., 28, 1197-1210, 1994.

Hong, S. Y., Noh, Y., and Dudhia, J.: A new vertical diffusion package with an explicit treatment of entrainment processes, Mon. Weather Rev., 134, 2318-2341, 2006.

Iacono, M. J., Delamere, J. S., Mlawer, E. J., Shephard, M. W., Clough, S. A., and Collins, W. D.: Radiative forcing by long-lived greenhouse gases: Calculations with the AER radiative transfer models, J. Geophys. Res.-Atmos., 113, D13103, doi:10.1029/2008JD009944, 2008.

Keene, W., Khalil, M. A. K., Erickson, D., McCulloch, A., Graedel, T. E., Lobert, J. M., Aucott, M. L., Gong, S. L., Harper, D. B., Kleiman, G., Midgley, P., Moore, R. M., Seuzaret, C., Sturges, W. T., Benkovitz, C. M., Koropalov, V., Barrie, L. A., and Li, Y. F.: Composite global emissions of reactive chlorine from anthropogenic and natural sources: Reactive Chlorine Emissions Inventory, J. Geophys. Res.-Atmos., 104, 8429-8440, 1999.
Kim, M. J., Farmer, D. K., and Bertram, T. H.: A controlling role for the air-sea interface in the chemical processing of reactive nitrogen in the coastal marine boundary layer, P. Natl. Acad. Sci. USA, 111, 3943-3948, 2014.

Li, Y., An, J., Min, M., Zhang, W., Wang, F., and Xie, P.: Impacts of HONO sources on the air quality in Beijing, Tianjin and Hebei Province of China, Atmos. Environ., 45, 4735-4744, 2011.

Lin, Y. L., Farley, R. D., and Orville, H. D.: Bulk parameterization of the snow field in a cloud model, J. Clim. Appl. Meteorol., 22, 1065-1092, 1983.

Liu, F., Zhang, Q., Tong, D., Zheng, B., Li, M., Huo, H., and He, K. B.: High-resolution inventory of technologies, activities, and emissions of coal-fired power plants in China from 1990 to 2010, Atmos. Chem. Phys., 15, 13299-13317, doi:10.5194/acp15-13299-2015, 2015.

Lowe, D., Archer-Nicholls, S., Morgan, W., Allan, J., Utembe, S., Ouyang, B., Aruffo, E., Le Breton, M., Zaveri, R. A., Di Carlo, P., Percival, C., Coe, H., Jones, R., and McFiggans, G.: WRFChem model predictions of the regional impacts of $\mathrm{N}_{2} \mathrm{O}_{5}$ heterogeneous processes on night-time chemistry over north-western Europe, Atmos. Chem. Phys., 15, 1385-1409, doi:10.5194/acp15-1385-2015, 2015.

Madronich, S.: Photodissociation in the atmosphere: 1. Actinic flux and the effects of ground reflections and clouds, J. Geophys. Res.-Atmos., 92, 9740-9752, 1987.

Millero, F. J.: Chemical oceanography, CRC press, Boca Raton, FL, USA, 1996.

Nenes, A., Pandis, S. N., and Pilinis, C.: ISORROPIA: A new thermodynamic equilibrium model for multiphase multicomponent inorganic aerosols, Aquat. Geochem., 4, 123-152, 1998.

Osthoff, H. D., Roberts, J. M., Ravishankara, A. R., Williams, E. J., Lerner, B. M., Sommariva, R., Bates, T. S., Coffman, D., Quinn, P. K., Dibb, J. E., Stark, H., Burkholder, J. B., Talukdar, R. K., Meagher, J., Fehsenfeld, F. C., and Brown, S. S.: High levels of nitryl chloride in the polluted subtropical marine boundary layer, Nat. Geosci., 1, 324-328, 2008.

Riedel, T. P., Wolfe, G. M., Danas, K. T., Gilman, J. B., Kuster, W. C., Bon, D. M., Vlasenko, A., Li, S.-M., Williams, E. J., Lerner, B. M., Veres, P. R., Roberts, J. M., Holloway, J. S., Lefer, B., Brown, S. S., and Thornton, J. A.: An MCM modeling study of nitryl chloride $\left(\mathrm{ClNO}_{2}\right)$ impacts on oxidation, ozone production and nitrogen oxide partitioning in polluted continental outflow, Atmos. Chem. Phys., 14, 3789-3800, doi:10.5194/acp-14-37892014, 2014.

Riemer, N., Vogel, H., Vogel, B., Schell, B., Ackermann, I., Kessler, C., and Hass, H.: Impact of the heterogeneous hydrolysis of $\mathrm{N}_{2} \mathrm{O}_{5}$ on chemistry and nitrate aerosol formation in the lower troposphere under photosmog conditions, J. Geophys. Res.Atmos., 108, 4144, doi:10.1029/2002JD002436, 2003.

Riemer, N., Vogel, H., Vogel, B., Anttila, T., Kiendler-Scharr, A., and Mentel, T. F.: Relative importance of organic coatings for the heterogeneous hydrolysis of $\mathrm{N}_{2} \mathrm{O}_{5}$ during summer in Europe, J. Geophys. Res.-Atmos., 114, D17307, doi:10.1029/2008JD011369, 2009.

Roberts, J. M., Osthoff, H. D., Brown, S. S., and Ravishankara, A. R.: $\mathrm{N}_{2} \mathrm{O}_{5}$ oxidizes chloride to $\mathrm{Cl}_{2}$ in acidic atmospheric aerosol, Science, 321, 1059-1059, 2008.

Roberts, J. M., Osthoff, H. D., Brown, S. S., Ravishankara, A. R., Coffman, D., Quinn, P., and Bates, T.: Laboratory studies of 
products of $\mathrm{N}_{2} \mathrm{O}_{5}$ uptake on $\mathrm{Cl}^{-}$containing substrates, Geophys. Res. Lett., 36, L20808, doi:10.1029/2009GL040448, 2009.

Ryder, O. S., Campbell, N. R., Shaloski, M., Al-Mashat, H., Nathanson, G. M., and Bertram, T. H.: Role of Organics in Regulating $\mathrm{ClNO}_{2}$ Production at the Air-Sea Interface, J. Phys. Chem. A, 119, 8519-8526, 2015.

Sarwar, G. and Bhave, P. V.: Modeling the effect of chlorine emissions on ozone levels over the eastern United States, J. Appl. Meteorol. Climatol., 46, 1009-1019, 2007.

Sarwar, G., Simon, H., Bhave, P., and Yarwood, G.: Examining the impact of heterogeneous nitryl chloride production on air quality across the United States, Atmos. Chem. Phys., 12, 6455-6473, doi:10.5194/acp-12-6455-2012, 2012.

Sarwar, G., Simon, H., Xing, J., and Mathur, R.: Importance of tropospheric $\mathrm{ClNO}_{2}$ chemistry across the Northern Hemisphere, Geophys. Res. Lett., 41, 4050-4058, 2014.

Shaw, W. J., Allwine, K. J., Fritz, B. G., Rutz, F. C., Rishel, J. P., and Chapman, E. G.: An evaluation of the wind erosion module in DUSTRAN, Atmos. Environ., 42, 1907-1921, 2008.

Simon, H., Kimura, Y., McGaughey, G., Allen, D. T., Brown, S. S., Osthoff, H. D., Roberts, J. M., Byun, D., and Lee, D.: Modeling the impact of $\mathrm{ClNO}_{2}$ on ozone formation in the Houston area, J. Geophys. Res.-Atmos., 114, D00F03, doi:10.1029/2008JD010732, 2009.

Simon, H., Kimura, Y., McGaughey, G., Allen, D. T., Brown, S. S., Coffman, D., Dibb, J., Osthoff, H. D., Quinn, P., Roberts, J. M., Yarwood, G., Kemball-Cook. S., Byun, D., and Lee, D.: Modeling heterogeneous $\mathrm{ClNO}_{2}$ formation, chloride availability, and chlorine cycling in Southeast Texas, Atmos. Environ., 44, 54765488, 2010.

Stockwell, W. R., Kirchner, F., Kuhn, M., and Seefeld, S.: A new mechanism for regional atmospheric chemistry modeling, J. Geophys. Res.-Atmos., 102, 25847-25879, 1997.

Stutz, J., Alicke, B., Ackermann, R., Geyer, A., White, A., and Williams, E.: Vertical profiles of $\mathrm{NO}_{3}, \mathrm{~N}_{2} \mathrm{O}_{5}, \mathrm{O}_{3}$, and $\mathrm{NO}_{x}$ in the nocturnal boundary layer: 1 , Observations during the Texas Air Quality Study 2000, J. Geophys. Res.-Atmos., 109, D12306, doi:10.1029/2003JD004209, 2004.

Tan, J., Duan, J., He, K., Ma, Y., Duan, F., Chen, Y., and Fu, J.: Chemical characteristics of $\mathrm{PM}_{2.5}$ during a typical haze episode in Guangzhou, J. Environ. Sci., 21, 774-781, 2009.

Tao, J., Zhang, L., Ho, K., Zhang, R., Lin, Z., Zhang, Z., Lin, M., Cao, J., Liu, S., and Wang, G.: Impact of $\mathrm{PM}_{2.5}$ chemical compositions on aerosol light scattering in Guangzhou - the largest megacity in South China, Atmos. Res., 135, 48-58, 2014.

Tham, Y. J., Yan, C., Xue, L., Zha, Q., Wang, X., and Wang, T.: Presence of high nitryl chloride in Asian coastal environment and its impact on atmospheric photochemistry, China Sci. Bull., 59, 356-359, 2014.
Thornton, J. A., Kercher, J. P., Riedel, T. P., Wagner, N. L., Cozic, J., Holloway, J. S., Dubé, W. P., Wolfe, G. M., Quinn, P. K., Middlebrook, A. M., Alexander, B., and Brown, S. S.: A large atomic chlorine source inferred from mid-continental reactive nitrogen chemistry, Nature, 464, 271-274, 2010.

Wang, T., Wei, X. L., Ding, A. J., Poon, C. N., Lam, K. S., Li, Y. S., Chan, L. Y., and Anson, M.: Increasing surface ozone concentrations in the background atmosphere of Southern China, 19942007, Atmos. Chem. Phys., 9, 6217-6227, doi:10.5194/acp-96217-2009, 2009.

Wang, T., Tham, Y. J., Xue, L., Li, Q., Zha, Q., Wang, Z., Poon, S. C. N., Dubé, W. P., Blake, D. R., Louie, P. K. K., Luk, C. W. Y., Tsui, W., and Brown, S. S.: Observations of nitryl chloride and modeling its source and effect on ozone in the planetary boundary layer of southern China, J. Geophys. Res.-Atmos., 121, 2476-2489, doi:10.1002/2015JD024556, 2016.

Wang, X., Wang, T., Yan, C., Tham, Y. J., Xue, L., Xu, Z., and Zha, Q.: Large daytime signals of $\mathrm{N}_{2} \mathrm{O}_{5}$ and $\mathrm{NO}_{3}$ inferred at $62 \mathrm{amu}$ in a TD-CIMS: chemical interference or a real atmospheric phenomenon?, Atmos. Meas. Tech., 7, 1-12, doi:10.5194/amt-7-12014, 2014.

Wedepohl, K. H.: The composition of the continental crust, Geochim. Cosmochim. Ac., 59, 1217-1232, 1995.

Xu, Z., Wang, T., Xue, L. K., Louie, P. K., Luk, C. W., Gao, J., Wang, S. L., Chai, F. H., and Wang, W. X.: Evaluating the uncertainties of thermal catalytic conversion in measuring atmospheric nitrogen dioxide at four differently polluted sites in China, Atmos. Environ., 76, 221-226, 2013.

Xue, L. K., Saunders, S. M., Wang, T., Gao, R., Wang, X. F., Zhang, Q. Z., and Wang, W. X.: Development of a chlorine chemistry module for the Master Chemical Mechanism, Geosci. Model Dev., 8, 3151-3162, doi:10.5194/gmd-8-3151-2015, 2015.

Zhang, L., Wang, T., Lv, M., and Zhang, Q.: On the severe haze in Beijing during January 2013: Unraveling the effects of meteorological anomalies with WRF-Chem, Atmos. Environ., 104, 11-21, 2015.

Zhang, L., Wang, T., Zhang, Q., Zheng, J., Xu, Z., and Lv, M.: Potential Sources of Nitrous Acid (HONO) and Their Impacts on Ozone: A WRF-Chem study in a Polluted Subtropical Region, J. Geophys. Res.-Atmos., 121, 3645-3662, doi:10.1002/2015JD024468, 2016.

Zhang, Q., Streets, D. G., Carmichael, G. R., He, K. B., Huo, H., Kannari, A., Klimont, Z., Park, I. S., Reddy, S., Fu, J. S., Chen, D., Duan, L., Lei, Y., Wang, L. T., and Yao, Z. L.: Asian emissions in 2006 for the NASA INTEX-B mission, Atmos. Chem. Phys., 9, 5131-5153, doi:10.5194/acp-9-5131-2009, 2009. 